Portland State University

PDXScholar

1984

\title{
Survey of language acquisition techniques provided by parents of talented and gifted children
}

\author{
Sharon Engen \\ Portland State University
}

Follow this and additional works at: https://pdxscholar.library.pdx.edu/open_access_etds

Part of the Education Commons, and the Speech Pathology and Audiology Commons Let us know how access to this document benefits you.

\section{Recommended Citation}

Engen, Sharon, "Survey of language acquisition techniques provided by parents of talented and gifted children" (1984). Dissertations and Theses. Paper 3393.

https://doi.org/10.15760/etd.5276

This Thesis is brought to you for free and open access. It has been accepted for inclusion in Dissertations and Theses by an authorized administrator of PDXScholar. Please contact us if we can make this document more accessible: pdxscholar@pdx.edu. 
AN ABSTRACT OF THE THESIS OF Sharon Engen for the Master of Science in Speech Communication, with an emphasis in SpeechLanguage Pathology, presented October 5, 1984.

Title: Survey of Language Acquisition Techniques Provided by Parents of Talented and Gifted Children.

APPROVED BY MEMBERS OF THE THESIS COMMITTEE:
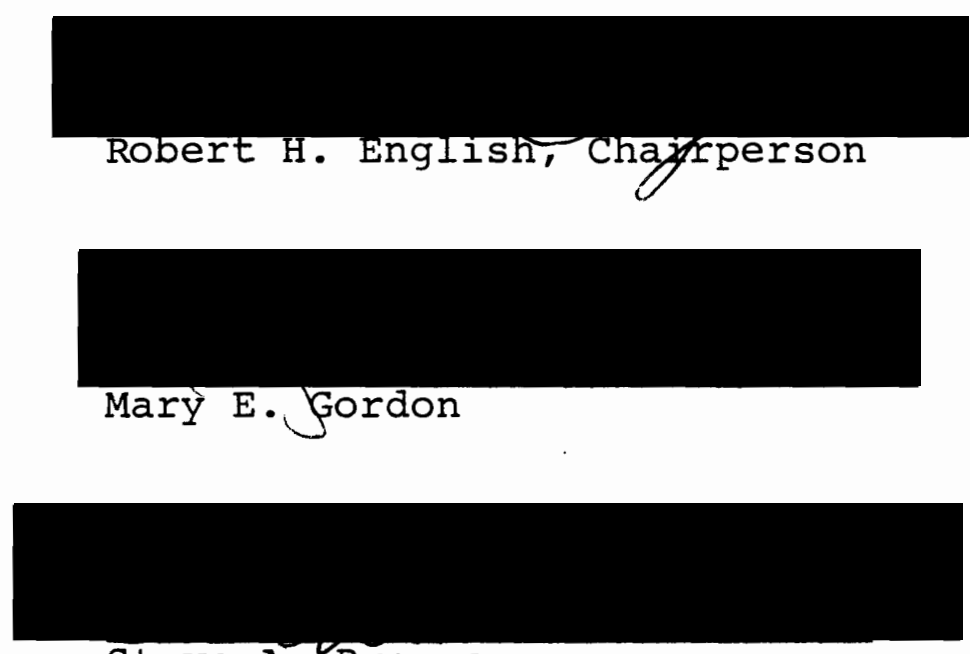

Steve A. Brannan

The ability to communicate is perhaps the most important gift afforded mankind, and any breakdown in this process greatly affects one's well being. Education begins in the cradle as adults are constantly talking and exposing the child to speech and to experiences that give him or her 
language (Hearsay, 1978).

Children's performance in school settings as well as their behavior in social groups is based upon their ability to communicate meanings to others. Children who are able to express fine distinctions in meaning will more successfully communicate their feelings, ideas, and attitudes to others (Wood, 1976). Parents are considered to be the major source of stimulation within the child's environment throughout the developmental years (Latzke, 1975).

Most of the studies on language acquisition techniques provided by parents have been addressed to the training of parents for prevention of language disabilities and disorders (Latzke, 1975). Few investigations have involved language acquisition of the superior functioning child (Patterson, 1981). Hence, the purpose of this study was to survey language acquisition techniques provided by parents of talented and gifted children (TAG) who were enrolled in the Beaverton School District Number 48 TAG program. The first question dealt with what materials and/or equipment did the parents use in aiding their child's language development. The second question dealt with which particular methods did the parents use in aiding their child in language acquisition.

The results of language acquisition methods and materials and/or equipment used in aiding language acquisition for their children was derived from answers to a questionnaire sent to 408 parents of TAG children in Beaverton, Oregon. Two hundred and eighty-six (70 percent) of the 408 
questionnaires returned were used in the tabulation of results.

Parents of the TAG students participating in this study employed a variety of materials and/or equipment in aiding their child's language acquisition. Reading books and educational television were the two most frequently used materials and/or equipment used by the parents. Reading books and educational television also were perceived as being most effective by the parents.

Parents of the TAG students participating in this study employed a variety of language acquisition methods. Four language acquisition methods were reported used by 85 percent or more of the respondents to this survey: provide a good example/model of adult language; encourage the child to express his/her thoughts and feelings (negative as well as positve); provide an open system of communication where the child is an active member of the conversation; and provide a semantically rich environment with a lot of opportunities to talk about things and directly experience them. These four methods were also perceived as being most effective by the parents.

In summary, the results showed that the parents of the TAG children were very active participants in their children's language acquisition, and the children were very active members of the conversation, free to express their thoughts and feelings. The findings of this investigator are also related to the results of the Bloom and Sosniak (1981) study of exceptionally talented and gifted children and the effect their parents had on their future. 


\section{SURVEY OF LANGUAGE ACQUISITION \\ TECHNIQUES PROVIDED BY PARENTS \\ OF TALENTED AND GIFTED \\ CHILDREN}

by

SHARON ENGEN

A thesis submitted in partial fulfillment of the requirements for the degree of

MASTER OF SCIENCE IN SPEECH COMMUNICATION :

with an emphasis in

SPEECH-LANGUAGE PATHOLOGY

Portland State University

1984 
TO THE OFFICE OF GRADUATE STUDIES AND RESEARCH:

The members of the Committee approve the thesis of

Sharon Engen presented October 5, 1984 .

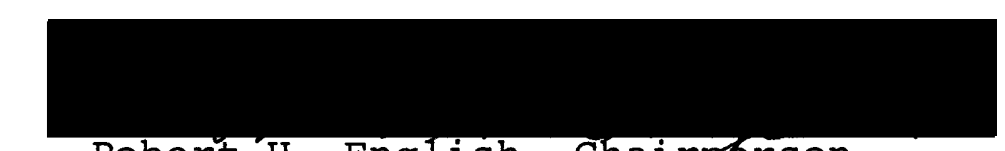

Rober't'H. English, Chaiggerson

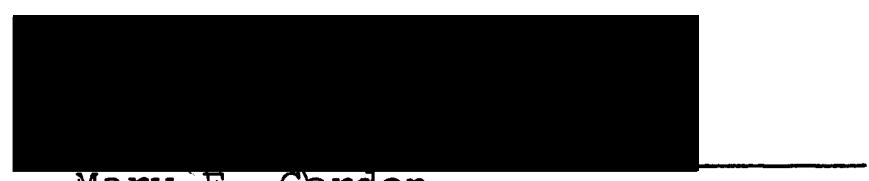

Mary E. Ggraon

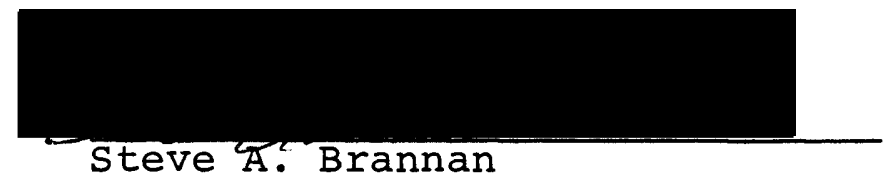

APP ROVED :

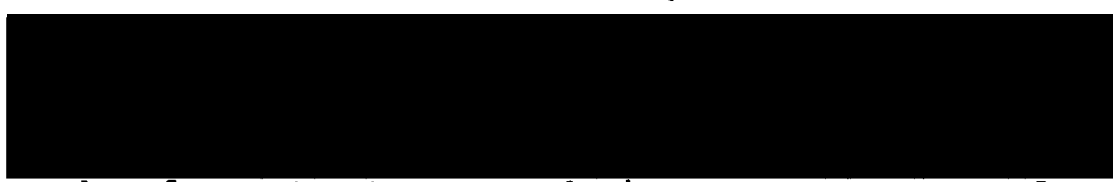

Theodore G. Grove, Chair, Department of Sneech Communication

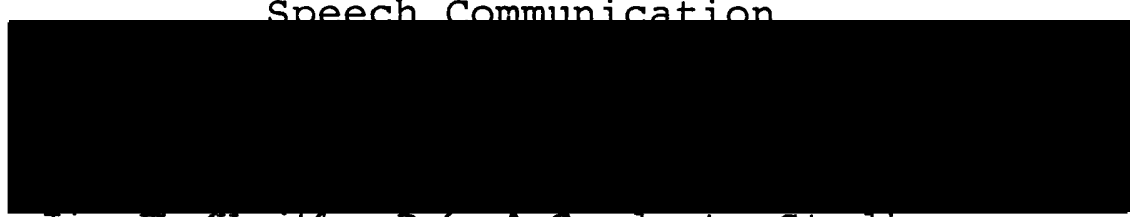

Jim H. Heath, Dean; Graduate Studies and Research 


\section{DEDICATION}

To David and Ryan

My Own TAG Children 


\section{ACKNOWLEDGEMENTS}

Many thanks to the entire staff of the Department of otolaryngology, OHSU, for providing me with employment so I could attend graduate school. Special thanks is extended to Dr. Schleuning, Chairman of ENT, who stood by my side through thick and thin, dried my tears and made me laugh. Dr. Everts provided me with hope, laughter, and served as a great role model for working day and night.

Sincere appreciation to my advisor and thesis director, Dr. Robert English. I feel fortunate to have received his wisdom and guidance. Mary Gordon is respected and loved by all of her students and fellow professionals, and no one shares these feelings more than I. My thanks to Dr. Ted Grove for his help with the statistical analysis and to all the staff at PSU.

Donna Dueker is a special friend who endured many hours listening to each and every detail of this thesis. Her support, encouragement, laughter, and friendship kept me going. Marilyn Caum is a dear friend who was an integral part of this thesis, both in typing it, and handing all the many details. Dr. Robert Johnson spent five months at his computer helping me do the statistics without ever a complaint. His intelligence is exceeded only by his kindness. My "support group," Jo, Karen, Kathie, Ray, and Sharon have been true friends in every sense of the word.

Mrs. Betty Flad, Director of the Beaverton TAG program allowed me to conduct my study with the District, as well as provided me with encouragement and advice. To her and all the TAG parents, my sincere appreciation.

Much love and gratitude to David and Ryan, my two TAG sons. I love you very much, and I thank you for holding the light at the end of the tunnel. 
TABLE OF CONTENTS

Page

DEDICATION

iii

ACKNOWLEDGEMENTS . . . . . . . . . . . . . I iv

LIST OF TABLES . . . . . . . . . . . . . . vi

LIST OF FIGURES . . . . . . . . . . . . . . . vii

CHAPTER

I INTRODUCTION AND STATEMENT OF PURPOSE 1

Introduction . . . . . . . . . . . 1

Statement of Purpose ......... . . . 3

Definition of Terms . . . . . . . . . 4

II REVIEW OF THE LITERATURE 6

Language Learning Theories . . . . . 6

Language Acquisition and Development . . 12

Language Acquisition Methods . . . . 15

III METHODS AND PROCEDURES 24

Methods . . . . . . . . . . 24

Procedures ............. 27

IV RESULTS AND DISCUSSION $\quad 34$

Results .............. 34

Discussion ............ . . 45

V SUMMARY AND IMPLICATIONS 61

Summary . . . . . . . . . . . 61

Clinical Implications ........ 63

Research Implications .. . . . . . 64

$\begin{array}{ll}\text { SELECTED BIBLIOGRAPHY } & 67\end{array}$

$\begin{array}{ll}\text { APPENDICES } & 71\end{array}$ 


\section{LIST OF TABLES}

TABLE

Page

I Materials and/or Equipment Percentages

Used . . . . . . . . . . . . . . .

II Language Acquisition Methods:

Percentages Used . . . . . . . . . .

III Perceived Effectiveness of Materials and/or Equipment Used

IV Materials and/or Equipment Percentage

Per Rank Position

$\mathrm{V}$ Perceived Effectiveness of Language

Acquisition Methods Used . . . . . . .

VI Language Acquisition Methods Percentage

Per Rank Position 


\section{LIST OF FIGURES}

FIGURE

Page

1. Percentage of Parents who Include a Given

Material and/or Equipment in Aiding

Their Child in Language Acquisition

2. Percentage of Parents Who Include a Given

Method in Aiding Their Child in

Language Acquisition . . . . . . . .

3. Perceived Effectiveness of Materials and/

or Equipment Used by Parents in Aiding

Their Child in Language Acquisition . .

4. Perceived Effectiveness of Methods Used by Parents in Aiding Their Child in

Language Acquisition 


\section{CHAPTER I}

\section{INTRODUCTION AND STATEMENT OF PURPOSE}

\section{Introduction}

Communication is a universal need. The necessity to express thoughts and to receive the thoughts and ideas of others is a need that cannot be suppressed or ignored. Education begins in the cradle as adults are constantly talking and exposing the child to speech and to experiences that give him or her language (Hearsay, 1978). The young child must derive information about language from the speech he or she hears, including the sentences spoken by adults (Nelson, Carskaddon, and Bonvillian, 1976; Snow, 1972). Verbal interaction between parent and child has been the focus of many studies (Cazden, 1972; Dale, 1976; Moerk, 1976; Phillips, 1973; Seitz and Stewart, 1975; Snow, 1972, 1979; Wood, 1976). Children's performance in school settings as well as their behavior in social groups is based upon their ability to communicate meanings to others. Children who are able to use words to express fine distinctions in meaning will more successfully communicate their feelings, ideas, and attitudes to others (Wood, 1976).

Normal language acquisition depends on heredity, rate of maturational development as well as intact systems for 
motor development, receiving language, processing language, and expressing language (Latzke, 1975). Assuming a child's physiological systems are intact, much of the available evidence supports the general prediction that the amount and quality of stimulation within a child's environment is the most important external factor affecting the rate of language development (Latzke). Even the rationalists, who are in direct opposition to this theory and who maintain that genetic structure determines language development, agree that environmental factors can affect the quality of language learned by the child (Hopper and Naremore, 1973). Parents are considered to be the major source of stimulation within the child's environment throughout the developmental years (Latzke) .

Further investigation of the literature has presented evidence showing parents do play a fundamental role in the acquisition of language and in determining the quality of language achieved by their children. Parental attitudes together with the emotional environment they create, the speech models they present, the corrective feedback they offer, and the quality of stimulation they provide are all vital elements in the language acquisition process (Latzke, 1976). Studies indicate, however, that many parents lack the necessary knowledge and training which enable them to provide systematic stimulation helpful for the child (Latzke, 1975). By acknowledging the major role parents play in their child's language acquisition, the professional has the responsibility to 
explore effective and efficient methods for enhancing the parents' understanding and skills in providing systematic stimulation and training for their children (Latzke, 1975).

Most of the studies on language acquisition techniques provided by parents have been addressed to the training of parents for prevention of language disabilities and disorders (Latzke, 1975). Few investigations have involved language acquisition of the superior functioning child (Patterson, 1981). It is known that gifted children will ordinarily not "blossom" to the full extent on their own (Guilford, 1975). An apparent need, therefore, exists to investigate the role parents play in their child's language development and subsequent success in school. The present study was designed to survey language acquisition techniques provided by parents of talented and gifted children, ranging in age from 8 to 12 years.

\section{Statement of Purpose}

The purpose of this study was to survey language acquisition techniques provided by parents of talented and gifted children. More specifically, the investigation was designed to determine the nature of language methodologies utilized by parents of school aged children between the ages of 8 to 12 years who had been identified as functioning in the superior and above range of intellectual ability.

This investigation desired to answer the following questions: 
1. Which particular materials and/or equipment did the parents use in aiding their child in language acquisition?

2. Which particular methods did the parents use in aiding the child in language acquisition?

\section{Definition of Terms}

For the purpose of this study, the following operational definitions were utilized:

\section{Language}

A language is a code whereby ideas about the world are represented through a conventional system of arbitrary signals for communication. Linguistic signals are units of sound such as words or sentences that are vocally produced or units of movement that are manually produced (Bloom and Lahey, 1982).

\section{Gifted Child}

A gifted child is a student with intelligence consistently above the average child.. Gifted children include about 3 to 5 percent of the student population (Beaverton School District, No. 48, 1982).

Language Acquisition (Transformationalists)

According to this view, the child relies on hypothesis testing. As a linguistic creator, the child does not need to be taught in any programmed institution such as a school. The Transformationalist's theory of language acquisition is based on innate, genetic inheritance for speech with the child being an active agent (Casteel, 1982; Dale, 1976). 
Language Acquisition (Structuralists)

This theory states language must be taught to the child through specific reinforcements. If the child is not reinforced, he will not learn to talk. Acquisition of language is the result of training and habit with the child as a passive agent (Casteel, 1982; Dale, 1976). 


\section{CHAPTER II}

\section{REVIEW OF THE LITERATURE}

The present review of the literature will confine itself to three subtopical areas that deal with transformationalist's and structuralist's language learning theories, language acquisition or development, and language acquisition methods.

\section{Language Learning Theories}

Traditionally, there have been two divergent positions regarding the question of man's language ability. At one extreme of the continuum, it is claimed that no linguisitc structure is innate, that language is learned through experiences. In John Locke's vivid phrase, children begin as tabulae rosae (blank states). Children are considered to learn language through general learning principles, usually assumed to be the same in many species of organisms. This is referred to as the empiricist or structuralist position (Dale, 1976) .

At the opposite extreme of the continuum is the rationalist or transformationalist position. The structure of language is regarded to be specified, to a large degree, biologically. The function of experience is not so much to teach directly as it is to activate the innate capacity and turn it into linguistic competence (Dale, 1976). 
Two important differences exist between these positions. The structuralist view holds that very little "psychological structure" is innately specified, while the transformationalist view claims a great deal is specified. This is a difference of degree, but it is of a very large degree. The structuralist acknowledges there are certain innate abilities but insists they are relatively simple, like the ability to form associations. The transformationalist does not deny experience has a function, for children must hear language in order to learn to speak and eventually do speak the language spoken in their communities (Dale, 1976).

The second difference between these two positions is absolute. In the structuralist or empiricist view, the child has no special ability for language, only general abilities to learn. Language is induced from experience by means of the same process responsible for other aspects of mental development. In the rationalist or transformationalist view, there exists a specific and strong capacity for language. Language is considered species-specific and species-uniform by the transformationalists. Both species-specificity (only humans) and species-uniformity are suggestive of the innateness hypothesis (Dale, 1976).

According to the structuralist position, language is the result of general learning abilities, and linguistic competence is considered to be a function of both learning ability and intelligence. The transformationalist position claims language is part of the specific biological endowments of man 
(Dale, 1976).

In the remainder of this section, thoughts will be narrowed to two major categories or theories, one referred to as transformationlist and the other as structuralist.

Transformationlist Theory

Basic principles of the transformationalist model are:

1) use of a deductive approach in language study; 2) language universals; 3) innateness of language; and 4) transformational grammar deep in surface structure (Casteel, 1982).

Chomsky disagreed with the structuralists in their stance of language acquisition being pruely learned, i.e., Stimulus $(S-R)$. What the child hears does not always appear to be a perfect model. He does state there are some $S-R^{\prime} S$ in learning to speak eloquently. For example, if a large enough corpus of language is made available to the child, he will acquire language. Hence, parents should expose the child to a large corpus of language. This is not being "taught" language, rather it is being "bathed in it (Casteel, 1982; Dale, 1976)."

Chomsky is of the opinion that the strucutralist or behavioralist view of language acquisition is erroneous. If language is merely a matter of habit, how can one account for the fact that most individuals sentences and words have never been used or heard before? Chomsky believes it is possible to answer these questions within a behavioral framework but only on a very limited basis (Casteel, 1982). 
Chomsky is looking for universals. He believes one should postulate universals and form universal grammar. He calls this "Property $P, "$ which is organic and in the brain. The transformationalists believe in the innateness of language and deep structure which is unobservable. The innate capacity for language creativity is attributed to people (Dale, 1976). Linguistic universals are possible, because they reflect a universal nature of the human and his mind (Casteel, 1982). This is based on pre-set or innate potentials. Language skills are easily "wired in" at some time. According to the transformationalist theory, children are born with distinctive personalities and begin life in an active mode. Intrapersonal forces such as biological maturation, genetic makeup, and creative abilities influence a child's language acquisition. Much of children's communication about their world, themselves, and others comes from their ability to analyze things on their own. A set of forces within the child affect his/her development (Friedrich, 1983; Wood, 1976).

According to Dale (1976), Lenneberg proposes language is rooted in biological foundations. He states humans have the innate capacity to acquire language without systematic training, and they do not have to be taught how to use language (Casteel, 1982; Dale, 1976).

Transformationalists see grammar as surface structure. on the other hand, the structuralists see language as a description of morphemes plus order in a sentence. The transformationalist says that the syntactical model is more 
complex. There has to be something more than an observed gathering of information to acquire language. That which is observable, Chomsky calls surface structure, and he postulates an underlying level of deep structure (Casteel, 1982). The second major language learning theory to be discussed is the strucutralist or empiricist theory.

\section{Structuralist Theory}

Some of the basic principles of the structuralist model are: 1) use of the scientific method in language study (inductive); 2) language is a result of training and habit; 3) there are no language universals; and 4) the model for language is the phoneme, morpheme, and syntax (Casteel, 1982; Dale, 1976).

The structuralists make use of the scientific method in language study. Methodology for collecting information on language acquisition and development is done by the inductive approach, basing findings solely on what they determine from the data. More objectivity is used in obtaining their data than is used by the transformationalists.

The structuralists believe language is a result of training and habit. They are more comfortable in analyzing language than studying language acquisition. They take a behaviorist approach to language and stress training and habit (Dale, 1976).

There are no language universals according to the structuralist model. Structural proponents believe there are more 
differences than similarities among languages, and they emphasize the uniqueness of each language system.

The structuralist model for language consists of the phoneme, morpheme, and syntax. The fundamental element is the phoneme, a class of sounds which are categorized together. Morphemes, consisting of one or more phonemes, have meaning by themselves whereas a phoneme does not (Casteel, 1982). The end product of language acquisition is adult linguistic competence. In a sense, language acquisition is just the opposite of linguistic performance. In general, speaking and listening require a conversion of knowledge into action, whereas in language acquisition, the sentences the child hears and produces must be converted into knowledge (Dale, 1976) .

Two grammatical models developed for adult language, transformational grammar and structuralist grammar, have been proposed for child language. The two models differ primarily in that transformational grammar provides a basically grammatical level of representation (subject and predicate) whereas case grammar or structuralist grammar provides a fundamentally more semantic level of analysis (Dale, 1976). Despite these differences, certain commonalities exist between these two models regarding acquisition of language.

The striking similarities among child languages, despite the superficial differences among adult languages heard, suggests that children bring to the problem of language acquisition, as part of their biological endowment as human beings, 
a universal and relatively structured learning ability. Whether this ability is viewed as primarily grammatic, semantic, or cognitive is an issue that can be resolved only through further understanding of adult language, child language, and cognitive development in children (Dale, 1976).

\section{Language Acquisition and Development}

This investigator believes that to understand and evaluate language acquisition among gifted children, it is necessary to understand normal language development. Hence, this section will provide a brief review of the literature dealing with language acquisition or development.

For a long time, it has been generally acknowledged that the need for physical comfort is among the needs of infants. Infants' cries of discomfort have been recognized as among the earliest signs of communication. There is growing evidence that the social and affective needs of infants can influence their behavior so that sounds of comfort and vocalizations that accompany positive affect are counted as signs of communication (Bloom and Lahey, 1982).

Three important aspects of such early signs of communication are: 1) early sounds and movements are the infant's own and are discovered by the infant as he moves, twists, turns, and breathes; 2) sounds and movements made by infants are part of the event being communicated in that the infant's cries are indications of both discomfort and satisfaction; and 3) these early behaviors in infancy inevitably have their 
developmental couterpart in children's later, more mature behaviors. Infancy behaviors gradually evolve into more complex forms of communication. In infancy, children learn that vocalization can perform certain functions for them. In the period from 6-18 months, a child learns that using his voice is doing something and is a form of action which soon develops its own patterns and its own significant contexts (Bloom and Lahey, 1982).

Around 2-3 months, the normal child rolls over. About the time he is doing this, the cooing starts which is making vowel-like sounds without consonants. At 4 months, the child can sit supported with pillows. This is about the same time period the child starts babbling. Usually, the second consonant is the same as the first consonant resulting in production of redundancy, e.g., "ga-ga." At 6 months, the child is able to sit alone and at 8 months, babbling starts to display vocal inflection. Between 6-9 months, accompanying gestures such as pat-a-cake and other social interaction occur with oral communication (Casteel, 1982).

Between 10-18 months, the normal child will say his first word. By 12 months of age, he will use 1-3 words. At 18 months of age, the child uses 15-25 words. By 24 months, there is a rapid growth in language acquisition and the child uses 50-300 words. The child begins using connected speech between 24 and 26 months. There are wide variations among children in vocabulary development which is considered normal. These data only approximate guides in language acquisition 
and development and represent the upper age limits at which children begin speaking (English, 1981; Gordon, 1981). By 30 months, the child uses 300-500 words and uses speech to precede action, such as, "I pick up," and speech is 70 percent intelligible in context. By 36 months, the child's speech is 70-80 percent intelligible, and he may use up to 500 words with a noticeable increase in vocalization. There is about 90 percent intelligibility at 42 months with the child using 400-800 words with 3 to 4 words per sentence on the average. speech should be 100 percent intelligible in context by 48 months, although misarticulations are still present. At this age, the child comprehends about 1500 words and uses 800-1100 words using about 4 words per sentence. By $41 / 2$ years, the normal child will use between 1000-1400 words with 4 to 5 words per sentence. The 5 th year is marked by use of up to 1600 words with many 4-, 5-, and 6-word sentences with an average of 5 words. At $51 / 2$ years, the child understands most simple, compound, and complex sentences of ordinary length, although he may become confused if they are complicated (English, 1981).

It has been noted that the rapid acquisition of language in children is a symbolization process which has both an encoding and decoding aspect of both spoken and written language. The child receives the message and breaks down the code and encodes it as a response (Gordon, 1981).

Speech is a neuro-motor act. The child has the ability to produce sound by the movement of muscles and the adjustment 
of structures in response to neural-impulses. Additionally, speech is a linguistic or communicative act with the child having the ability to symbolize orally thoughts, feelings, and emotions (Casteel, 1982).

Among individuals serving as communication models for the child in his acquisition of language are parents, teachers, and/or clinicians. The parents' attitudes and beliefs have a strong influence on the child (Dale, 1976; English, 1981; Wood, 1976) and have been shown to be more important than socioeconomic conditions. Wood, in reviewing the work of Bernstein, notes verbal interaction in families can take one of two roles: 1) a person-oriented family style is an open role system such that each member of the family has discretion in his or her role. More decisions are offered which equal greater harmony and ability to communicate personal choices. Parents read and talk to their children, and use a rule-making system; and 2) a position-oriented family style where each person has a particular role and family roles are assigned rather than achieved. It is a rule-giving system in which communciation cannot be open, children do not cope as well, and there exists a greater likelihood that the child will develop a restricted code of language.

\section{Language Acquisition Methods}

In the previous section, it has been noted that the acquisition of language necessitates a rich environment, providing a model and stimulation for the child. Effective 
methods provided by parents for language acquisition in their children are numerous. Gifted children often require unique instructional methods. Parents of these children have been and will continue to be role models for their intellectually superior children (Beaverton School District, No. 48, 1982). Most human beings are born with enormous potential in one area or another, and parents demonstrate extraordinary power over their children (Pines, 1982). A research team at the University of Chicago headed by Bloom, one of the nation's foremost educational researchers, investigated how 100 exceptionally talented people, ages 17-35, reached the top of their fields. After the research team compiled an analysis of the life histories of these outstanding people, the team identified several conditions standing apart from native gifts and, in almost every case, appear to be crucial in producing excellence. In the families of these successful individuals, environmental conditions vary somewhat for different kinds of talent, but, in all cases, they involve these factors: 1) someone in the family (usually one or both parents) had a personal interest in the child's talent and provided great support and encouragement in that area; 2) most of the parents were role models in their child's development of talent, especially in terms of life style; 3) there was specific parental encouragement of the child to explore the area, participate in home activities related to it, and join the family in related activities; 4) these small signs of interest and capability by the child were rewarded; 5) parents took for granted 
their children would learn in the talent area, just as they would learn language; 6) expected behaviors and values related to the talent area were present in the family; 7) teaching was informal and occurred in a variety of settings resulting in the early learning being exploratory and much like play; 8) the family interacted with a tutor/mentor and received information to guide their child's specific tasks; 9) parents observed practice, insisted the child put in the required amount of practice time, provided instruction where necessary, and rewarded the child whenever the child excelled; 10) parents sought special teachers and special instruction for their child; and 11) parents encouraged participation in events in which capabilities were displayed publically (Bloom and Sosniak, 1981; Callahan and Kauffman, 1982; Pines, 1982). The old saw that "genius will out," in spite of circumstances, was not supported by this study (Bloom and Sosniak, 1981). According to Bloom and Sosniak, key factors in motivating children are: 1) What does the home value? and 2) How much encouragement does the child receive at an early age? Bloom and Sosniak concluded in their study that the home plays a very important role in supporting the child in talent development. Evidence strongly suggests that those gifted children who realize their potential most completely have families that are stimulating, directive, supportive, and rewarding of their special abilities (Callahan and Kauffman, 1982). It is frequently assumed that parents of gifted children also are gifted. This assumption has led to the 
conclusion the parents will know the most appropriate strategies and have the necessary resources for dealing with giftedness at home and at school. Unfortunately, both the assumption and the conclusion are often false. There is no evidence that parents of a gifted child will necessarily have the skills required to make the most of their child's abilities and schooling (Passow, 1979; Robinson, 1977).

Early research of the family backgrounds of intellectually gifted children from middle-class American homes revealed a positive relationship between children's achievement and their parents' encouragement of initiative, independence, and pressure to excel (Terman and Oden, 1959).

Two common forms of parental response that could play a supportive role in the child's acquisition of syntax are expansions and extensions (Cazden, 1972). She defines expansions as an adult verbal response which is contingent on the child's previous utterance and which expresses in syntactically complete form the meaning of the child's utterance as the adult understands it. For example, the child would say, "Dog bark." and the adult would respond, "Yes, the dog is barking." She defines extensions as an adult verbal response which is contingent on the child's previous utterance and which presupposes a particular expansion, but then builds out from it along some dimension of meaning. For example, if a child said, "Dog bark." the adult would respond, "Yes, and the kitty is running after him." Expansions and extensions are both adult responses which are contingent on the child's 
previous utterance, but the nature of the contingency is slightly different in the two cases. To show the child there are other more meaningful ways of saying what he might say is important semantic training (Van Riper, 1978).

Weybright and Rosenthal (1981) describe techniques they have utilized successfully with parents of young children at the Portland Center for Hearing and Speech. Their methods of indirect language stimulation used with language impaired children have proven effective with their clients in building a language understanding which may increase syntactical development.

Another method for language acquisition has been proposed by Susedik and his wife who have four children, each having a 150+ IQ. According to Woodley (1983), the Susedik's attribute their children's intelligence to the intensive tutoring program that starts prior to birth. They talk to the womb, teaching alphabet, phonics, and social studies. Susedik states, "Any kid has a chance to be a genius, and we are here to prove it." Mrs. Susedik, a former college professor, bases her teaching method on love (Woodley).

According to educators, reading may be one of the most important activities parents can do for their child (Brinley, 1983; Durkin, 1966; Friedrich, 1983; Larrick, 1976; Richards, 1978; Unger, 1976). Experts report that what a parent does in the first few weeks of life can have a lasting influence on a child. By the time a child reaches several months of age, he or she should be read to regularly. 
While many parents do not feel themselves qualified in the area of education, the fact is, if one is a parent--one is a teacher (Richards, 1978). Fifty percent of intellectual development takes place between birth and 4 years of age, and by the time the child enters kindergarten, much has been determined in his or her life. The benefits of reading aloud to children are many. It is helpful in developing their vocabulary and listening skills, teaches them values, and helps them learn to like reading and to make it a part of their everyday lives (Durkin, 1966; Larrick, 1976; Richards, 1978). The idea that infants are capable of acquiring an education has tempted ambitious parents for centuries. Today, fashionable nursery schools not only interview 2 year olds for admission, but they charge parents $\$ 1,200$ a year for two mornings of schooling a week. They also report applications outrunning openings by as much as 5 to 1 (Friedrich, 1983). This vogue, started in New York City, is spreading across the country with many organizations providing educational play, commercial reading programs, educational toys, and workbooks for children (Brinley, 1983; Dore, Franklin, Miller and Ramer, 1975; Friedrich, 1983; Larrick, 1976; Ratner and Bruner, 1977; Unger, 1976; Van Hattum, 1982).

Parent meetings can be organized for the purpose of teaching specific skills for enriching the curriculum from the home base, with common household items such as pots and pans (Brinley, 1983). Parent meetings have proven to be effective for improving parent awareness and parental attitudes 
(Hubbard, 1976; Mathews, 1981; Weybright and Rosenthal, 1981). Educational television programs educated parents as well as children when they first appeared over 15 years ago. Innovative programs such as Sesame street, Mr. Rogers, and The Electric Company, educated parents in the numerous methods of aiding a child in language acquisition as well as the numerous audio and visual aids available (MCNitt, 1983). Home computer programs created an ideal learning environment teaching children with pictures as well as words and figures (McNitt). Children were taught auditory awareness for sounds as the parent called the child's attention to the sameness of some sounds, to rhymes and to rhythm (Unger, 1976; Friedrich, 1983).

The key point is that the nature of adult-child interaction may have a strong bearing on development. The important factor affecting the speed and ease with which children learn their language appears to rest in the richness of the corpus of language provided by parents and others (Friedrich, 1983; Wells, 1979; Wood, 1976). Interaction should emphasize semantic considerations of the child's. speech. The more relevant the interaction between adults and children, the more quickly and efficiently children may learn to use the more complex forms of language.

Language and its acquisition can be described, but one can only speculate on how children have acquired it. Much of what is known about language acquisition has come from studies of children in their natural environments. Many linguists 
say this is the way to learn how a child develops and processes language. Some linguists and speech-language pathologists gather limited language samples and analyze them for specific grammatical and lexical features while others have constructed tests or tasks to measure selected linguistic features. Many have depended on parent recall of how the child's language has developed (Darley and Spriesterbach, 1978).

This section has dealt with various language acquisition methods used by parents with their children. Language acquisition and the ability to communicate to express thoughts and ideas and to receive the thoughts and ideas of others is a universal need which is the right of every child (Hearsay, 1978).

The challenge of the gifted and talented provides parents and educators with opportunities to re-examine the conceptual framework of education: Perhaps never in the history of this country and the world has the identification, nurturance, and education of those who are gifted and talented been more critical to society. To the extent that parents and educators succeed, they will meet the needs of not only the gifted and talented students, but all children, and they will develop the conceptual models for future education (Thomason, 1981).

There has been, to date, a lack of information dealing with language acquisition techniques provided by parents of talented and gifted children (Patterson, 1981). The literature 
suggests a variety of language theories and methods utilized by parents, but there are little data relative to what parents of talented and gifted children actually use; nor are there any data showing which of the methods the parents consider to be effective in promoting language acquisition. 
CHAPTER III

\section{METHODS AND PROCEDURES}

\section{Methods}

\section{Subjects}

Subjects for this survey included the parents of 286 children in the $4 \mathrm{th}, 5 \mathrm{th}$, and 6 th grades who were identified by Beaverton School District Number 48 as being talented and gifted students with unusually high potential in one or more subject areas and who had unique instructional needs. The children attending the Elementary Talented and Gifted (TAG) Center, ranged in age from 8 to 12 years.

\section{Screening}

All of the subjects were parents of a child who met the following criteria of the Beaverton School District:

1. The child ranked in the $97 \mathrm{th}$, 98th, or $99 \mathrm{th}$ percentile on the Science Research Associates (SRA)-Educational Ability Series (EAS) test.

2. The child who ranked at the 99th percentile with a teacher recommendation was automatically qualified for the TAG program.

3. If a student was at the 97 th or 98 th percentiles on the EAS, four other areas were examined: mathematics, reading, composite score, and teacher recommendation. Each of 
the areas was assigned a value of 1 to 5 points. To qualify for the program, the child must have received a total of 20 points for placement.

4. Parents of children meeting the foregoing criteria were then sent letters recommending TAG placement together with a parent permission form permitting placement in said program (Beaverton School District, No. 48, 1982).

All parents included in the present investigation had children who met the stated criteria.

Instrumentation

A questionnaire (Appendix A) was designed by this examiner to yield information about language acquisition techniques provided by parents of talented and gifted children. Although there was no attempt to standardize a new instrument, attention was paid to both content and construct validity. Content relative to materials and/or equipment and language acquisition methods was based upon a review of the literature relative to techniques for facilitating language acquisition in children, consultation with this investigator's Prospectus Committee, and coursework taken at Portland State University (Casteel, 1982; English, 1981; Gordon, 1981). Information relative to structural format for the questionnaire was drawn from Alvino, McDonnel, and Richert (1981); Burgess, (1976); Dillman, (1978); and Moser and Kalton, (1971).

Three categories of data composed the questionnaire:
1) demographic data;
2) materials and/or equipment used in 
promoting language acquisition with their child; and 3) language acquisition methods the parents used in aiding language acquisition with their child.

The first category, demographic data, consisted of three forced-choice questions and one open-ended question designed to elicit information germane to the description of parents responding to the questionnaire. These questions were not numbered. Demographic questions utilized in this questionnaire were among those recommended by the Social Science Research Council in 1975 to foster standardization so that survey data collected from different researchers would be more comparable and useful for secondary and trend analyses (Sudman and Bradburn, 1982).

The second category, materials and/or equipment used in promoting language acquisition, was composed of five forcedchoice questions and three open-ended items developed by this investigator. Construct and content validity were established from the review of the literature and review by the Prospectus Committee. Parents were asked to circle the number(s) corresponding to any materials and/or equipment they used. From those items they circled as having used, parents were asked to rank order the five they found most effective with one (1) being the most effective, two (2) next, three (3) next, four (4) next, and five (5) last (Grove, 1984; Sudman and Bradburn, 1982).

The third category, language acquisition methods used by the parents with their child, consisted of ten forced 
choice questions developed by this investigator and reviewed by the Prospectus Committee. The parents were asked to circle any method(s) they used in aiding language acquisition with their child. From those items circled, they were asked to rank order the five they found most effective with one (I) being the most effective, and five (5) being the least effective (Grove, 1984; Sudman and Bradburn, 1982).

\section{Procedures}

A questionnaire (Appendix A), a letter of introduction (Appendix B), and a stamped, addressed return envelope were mailed to 408 parents of talented and gifted children enrolled in the Beaverton School District TAG program. Follow-up postcards (Appendix C) were sent to all of the parents two weeks after the initial mailing. The postcard served as a reminder to complete and return the questionnaire for those parents who had not done so, and a thank you for those who did. The parents read and responded to items listed on the questionnaire per instruction in each category (Appendix A).

Data coding

Data were transferred from the surveys to grid sheets and recorded according to item and questionnaire numbers. Data not related to a specific questionnaire item, such as "other materials and/or equipment" used, were recorded according to question and questionnaire numbers. 
Analysis of the Data

Of the 408 questionnaires, 286 (70 percent) were returned, yielding a very good response rate (Babbie, 1973). These data were analyzed under three topical headings utilizing specific statistical methods appropriate to data under each category.

Demographic data. Demographic data were analyzed by descriptive statistics with the mean, mode, and the range being reported for ages their child said his/her first word, spoke in sentences, and began reading. The mean, mode, and range were reported for the mother's and father's level of education. Frequency distribution reported in percentages was used to group grade levels $4 \mathrm{th}, 5 \mathrm{th}$, and 6 th, and which parent completed the questionnaire, mother or father (Babbie, 1973).

While "no answer" and "don't know" categories did not appear on the questionnaire in the demographic section, a separate category to deal with missing items was established by this examiner to allow consistency in the data analysis (Sudman and Bradburn, 1982). Percentages were reported on the total number of respondents with those failing to give ages being reported as a percentage of the total (Babbie, 1973).

For the purpose of consistency of data for ages at which the child spoke and read, the following clarifications were made for this study. In cases where there were 2 weeks 
to I month difference in age reported, the lower number was used; in cases where the parent reported the age as "Kindergarten," 5 years old was used; in cases where the parent reported the age as "First Grade," 6 years old was used. In cases where the parent reported a range, such as $11 / 2$ years to $21 / 2$ years of age, the middle of that range was used for analysis.

For the purpose of consistency in handling the data of the parents' level of education, the following clarifications were used: high school was equivalent to 12 years of schooling; bachelor's degree was equivalent to 16 years of schooling; master's degree was equivalent to 18 years of schooling; and doctorate was equivalent to 20 years of schooling. Doctorate included Ph.D., law degree, medical degree, dental degree, and pharmacist degree. For the purposes of this study, where parents specified an occupation, such as business school, insurance school, trades and crafts (mechanics, electrician, or beautician), rather than a diploma or degree, such responses were coded as "others" and specified. For this study, they were considered to be equivalent to 1 year of advanced training beyond high school (Sudman and Bradburn, 1982). If a parent did not indicate a Bachelor's degree, even though they stated they had four years of college, the parent was coded under the "College, Number of Years" section. In cases where a parent indicated an uneven number of years of college, such as 1 1/2 years, the lower number of years was reported. In cases where an individual held more than one degree, the 
parent was included in the category for the higher level of education.

For the purpose of this study and consistency of data under which parent completed the questionnaire, a separate category designated as "both parents" was established for those questionnaires specifying this answer.

Perceived effectiveness of materials and/or equipment. In view of the fact that respondents ranked only those items they identified as using, and some items were much more frequently used than others, the rank totals for each item on effectiveness of materials and/or equipment used were based on unequal numbers of respondents which made comparisons of those totals meaningless. Polson (1980) developed the following conversion formula to provide a basis for comparing the total rank values across items:

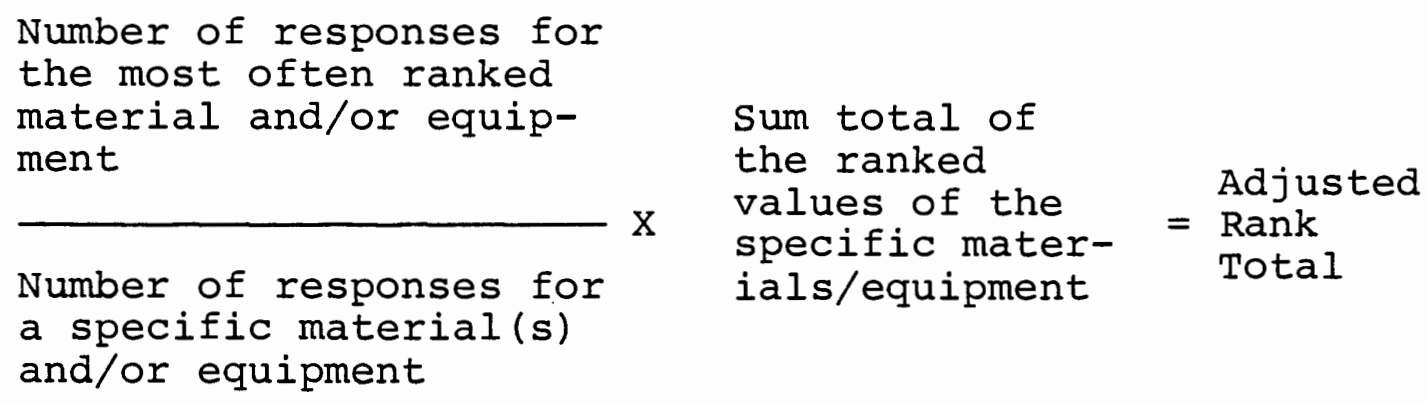

Number of responses for a specific material(s) and/or equipment

This conversion formula was applied to estimate the value of the rank totals if all items had been included in the ranking as frequently as the most frequently ranked item. Hence, the size of the ranks given a particular item were used to estimate the values of the missing rank data for that item (Polson, 1980). 
In this way, relative effectiveness among the items could be estimated without penalizing any given item for lack of frequent use. It should be cautioned, however, that inferences based on comparisons between total item ranks in this manner would be more credible for items with less missing data than those with more missing data (Polson, 1980). Missing data refers to items which were not given rank values, because respondents did not use those items (Grove, 1984).

Respondents ranked materials and/or equipment reported in the open-ended portion of the questions, other materials and/or equipment used but not listed as a question item. Rank values were adjusted to exclude those items prior to transferring the data from the questionnaire to grid sheets. The rank order of only the forced-choice items used by the parents was reported in the resulting data (Grove, 1984; Polson, 1980).

Responses which were inappropriate, such as "singing with my child," which was clearly not a material and/or equipment, were eliminated from any analysis in determining percentages.

For the purpose of consistency of data and clarification in analysis, each of the five categories was determined to include the following: 1) reading books included such items as newspapers, magazines, the Bible, poetry books, encyclopedias, picture books, and catalogues; 2) workbooks included such items as trace and say books, color and wipe-off books, word puzzle books, manipulative letters, coloring 
books, stencil books, sticker books, felt letter books, paint books, and paper and pencils; 3) commercial reading programs included such items as publishers reading and language programs as published by the Economy Company, Skillbooster series, and Child Guidance; and 4) educational toys included such items as alphabet blocks, puzzles, manipulative toys, card games, unspecified games, Milton Bradley building type toys, legos, and tinker toys.

Items listed in the "others" section were grouped according to commonalities. Specific subcategories formed included the following: a) audio aids which included such items as records and tapes, radios, cassettes; b) visual aids which included such items as flash cards, sight word cards, phonic cards, signs (stop, street, store), microfiche, chalkboard, cameras and photographs, labels; c) household items which included such items as typewriters, computers, microfiche reader; and e) school which included preschool, church school, play school. Due to a large number of parents who listed less than five rank values in this category, it was decided by this examiner to exclude the fifth ranking and determine percentiles on four rank values. For those questionnaires having less than four rank values, the missing data were handled by assigning a certain number to those questions on a random, "flip-coin" basis. Determination for the material and/or equipment assigned a number was determined by using the items which were chosen least frequently (Grove, 1984). 
Perceived effectiveness of language acquisition methods.

Language acquisition methods used by the parents with their child were analyzed by descriptive statistics with the frequency distributions of the number(s) corresponding to any method(s) the parents circled being reported. Rank values for these items were reported as percentages. Due to a "secretarial error," items 7 and 8 of this section were "collapsed," making one item out of it. By collapsing these data, it was necessary in some cases to readjust rank values with each item moving up one rank where parents ranked both items 7 and 8 (Grove, 1984). Where this readjusting of rank values left four or less rankings on any questionnaire, this examiner assigned a rank for the missing data. A random, "flip-coin" procedure was used, as in the materials and/or equipment section. For other questionnaires which did not include five rank values, a similar procedure of assigning a value was used. The conversion formula designed by Polson (1980) was used in determining adjusted rank totals. 
CHAPTER IV

RESULTS AND DISCUSSION

$\underline{\text { Results }}$

The purpose of this study was to survey language acquisition techniques provided by parents of talented and gifted (TAG) children. The two questions posed had two elements involved: 1) the materials and/or equipment used and the language acquisition methods employed; and 2) the relative effectiveness of each of the items employed. Hence, presentation of results will be reported under two headings, Methodologies Used and Effectiveness of Reported Methodologies.

Methodologies Used

Materials and/or equipment. Table I shows the number and percentages of parents who used materials and/or equipment in teaching their children during the language acquisition process. Here, it is to be noted that 97 percent used reading books; 93 percent used educational television programs; 90 percent used workbooks; 89 percent used educational toys; and 60 percent used commercial reading programs. These figures are visually demonstrated in Figure 1 to aid in analysis.

Language acquisition methods. Table II displays the number and percentages of parents who used particular language 


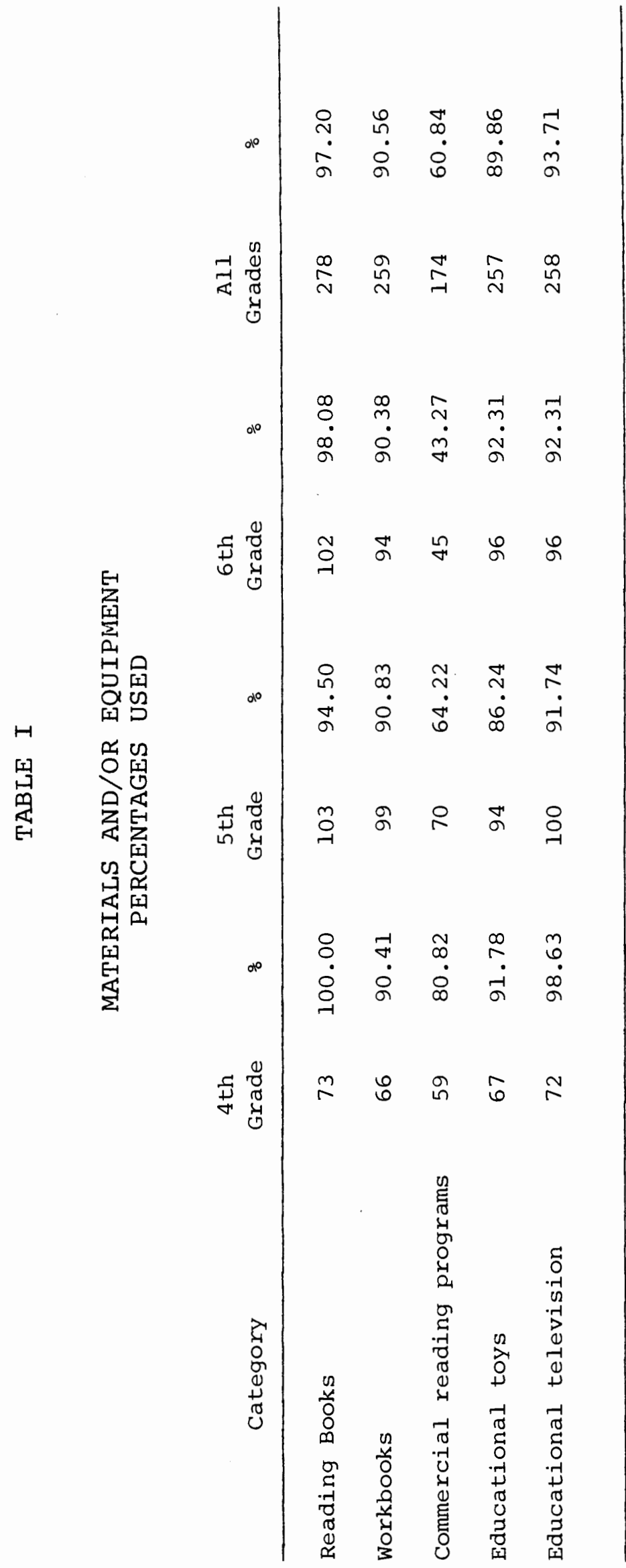




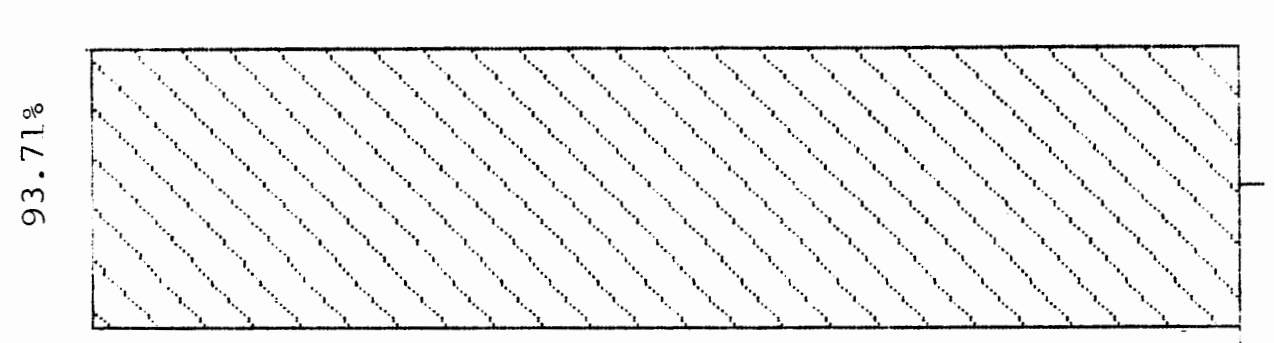

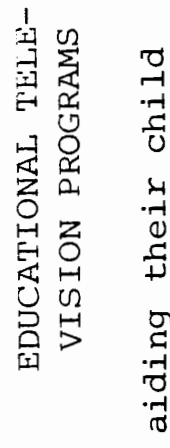

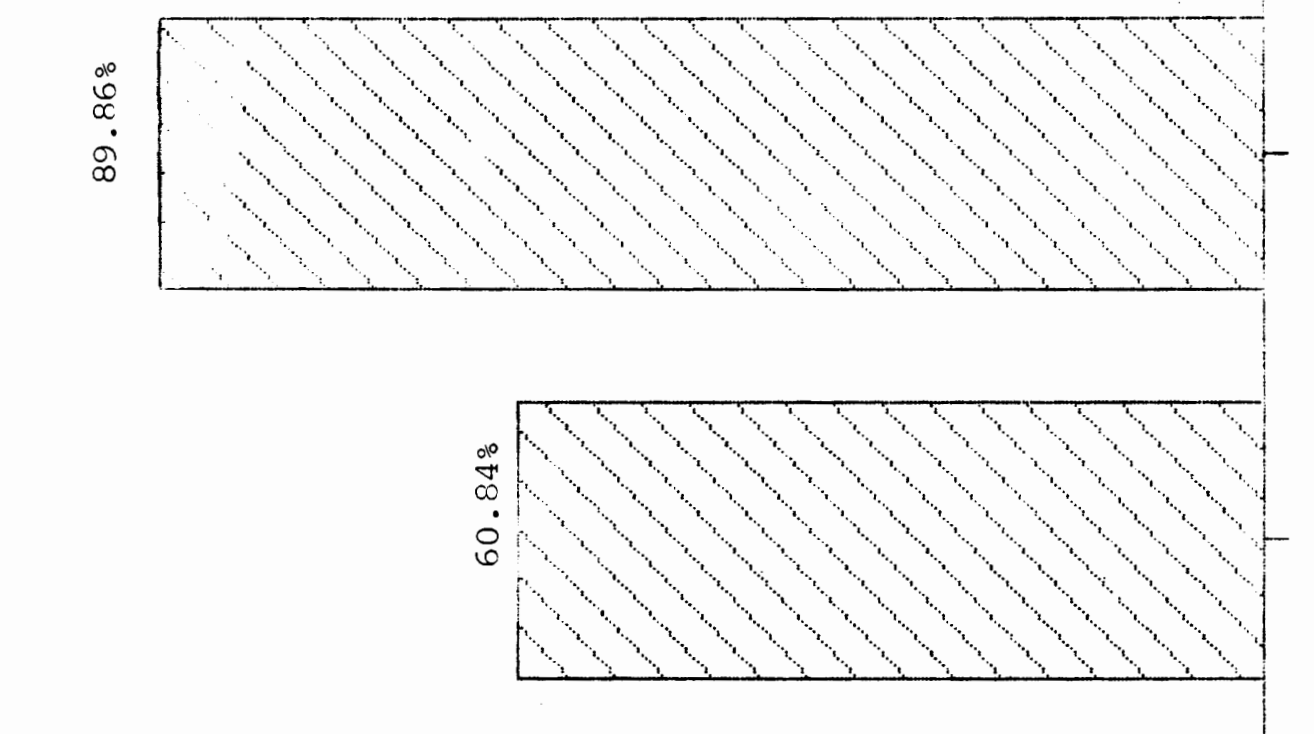

最

.

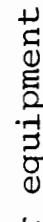

o ने द्वे

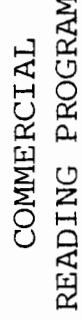

$-$

$\pi$

प्र

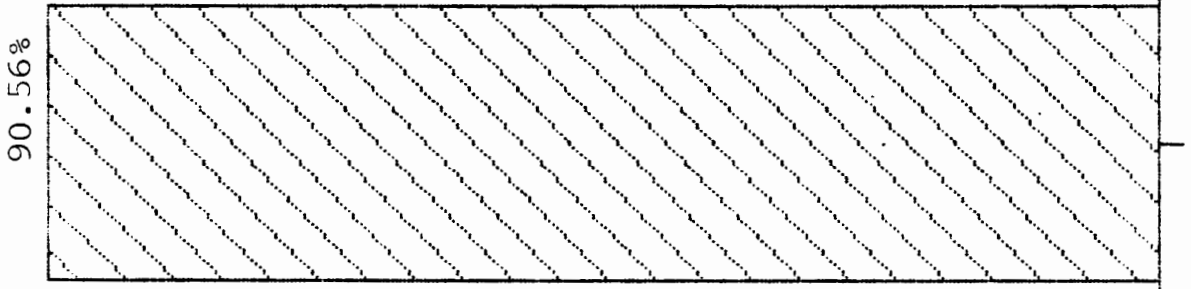

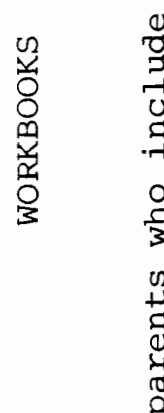

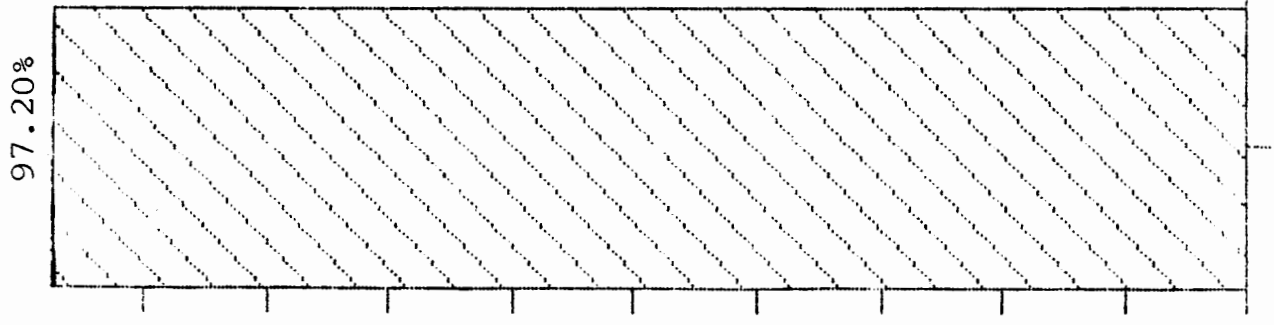

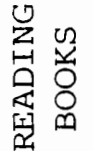

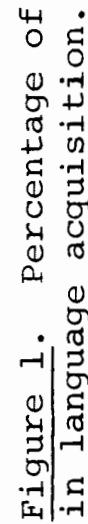




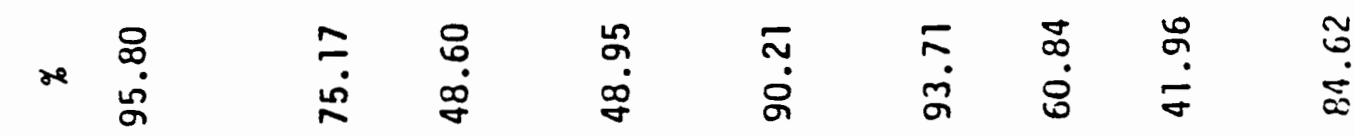

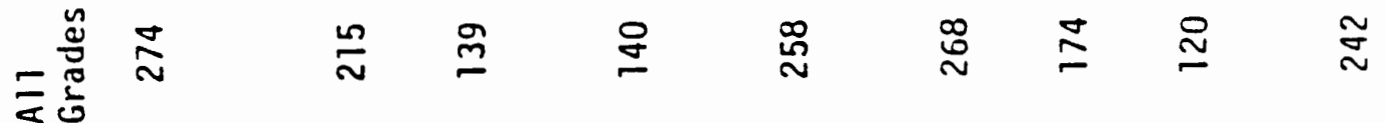

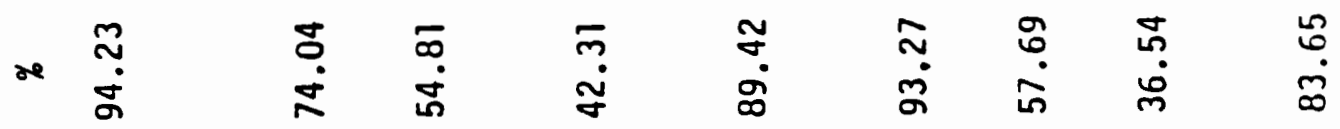
至

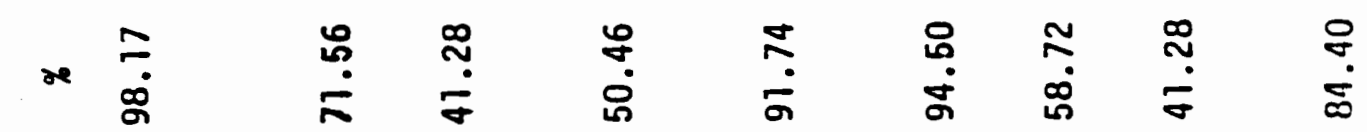

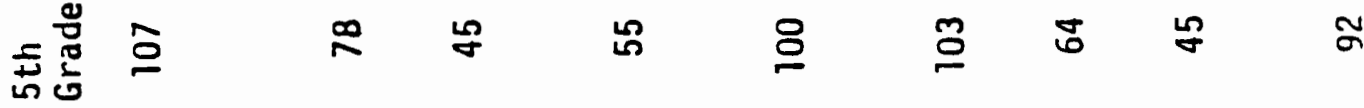

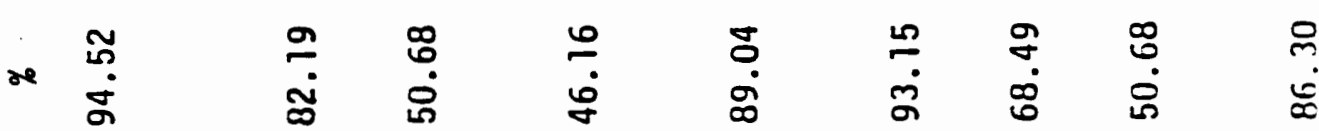

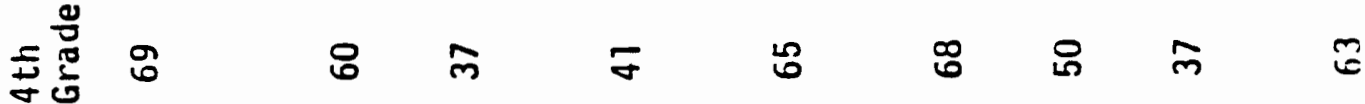

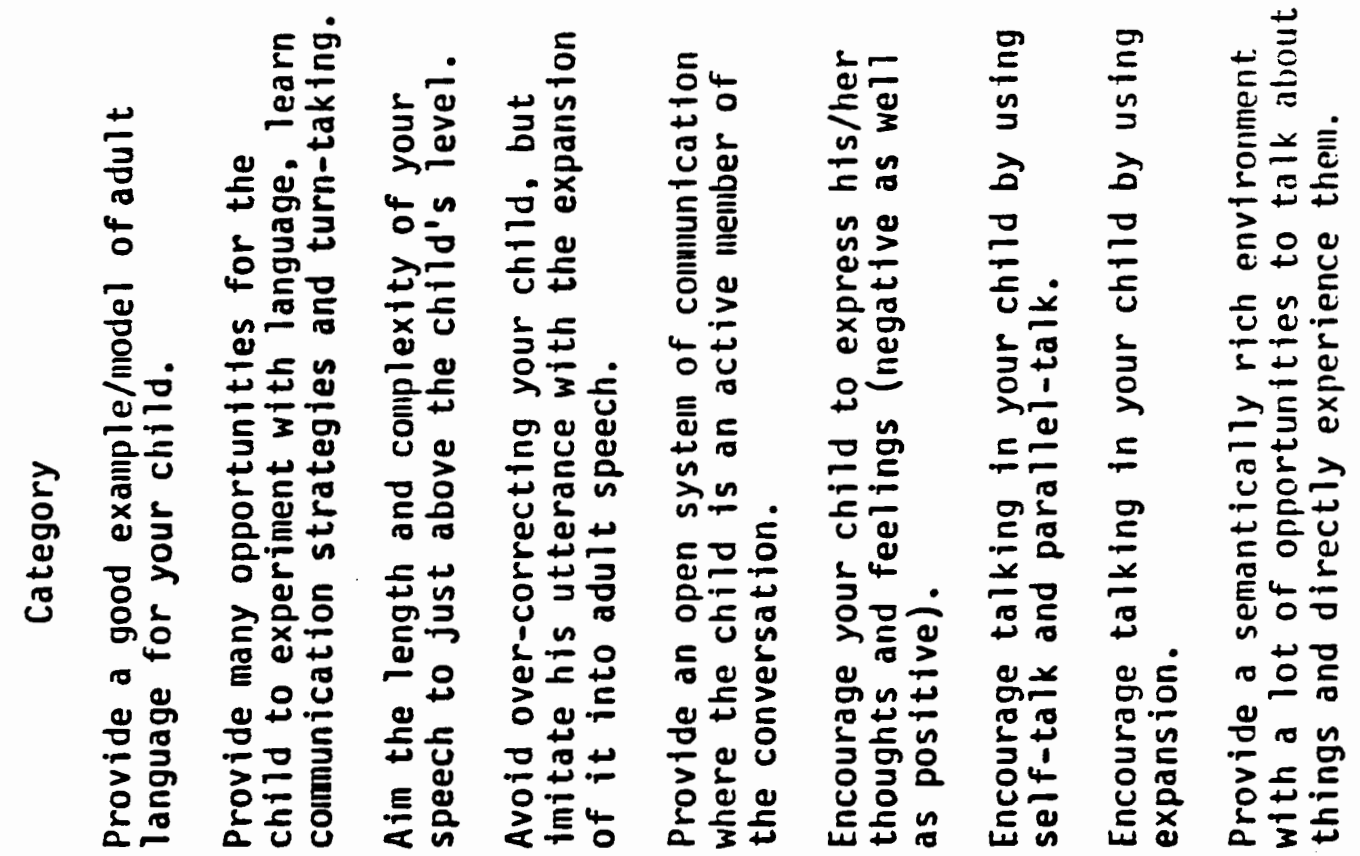
告 
acquisition methods in teaching their children during the language acquisition process. Examination of the data revealed the percentage of parents who used the following language acquisition methods: provide a good example/model of adult language ( 95.8 percent); encourage the child to express his/her thoughts and feelings, negative as well as positive, (93.7 percent); provide an open system of communication where the child is an active part of the conversation (90.2 percent); provide a semantically rich environment with a lot of opportunities to talk about things and directly experience them (84.6 percent); provide many opportunities for the child to experiment with language, learn communication strategies, and turn-taking ( 75.1 percent); encourage talking in the child by using self-talk and parallel-talk (60.8 percent); avoid overcorrecting the child but imitate his utterance with the expansion of it into adult language (48.9 percent); aim the length and complexity of your speech to just above the child's level (48.6 percent); and encourage talking in the child by using expansion (41.9 percent). Figure 2 visually demonstrates these percentages to aid in analysis.

Effectiveness of Reported Methodologies

Materials and/or equipment. In Table III can be found the comparison of adjusted rank totals of the relative effectiveness of the materials and/or equipment used by the parents. The materials and/or equipment were ranked with one 

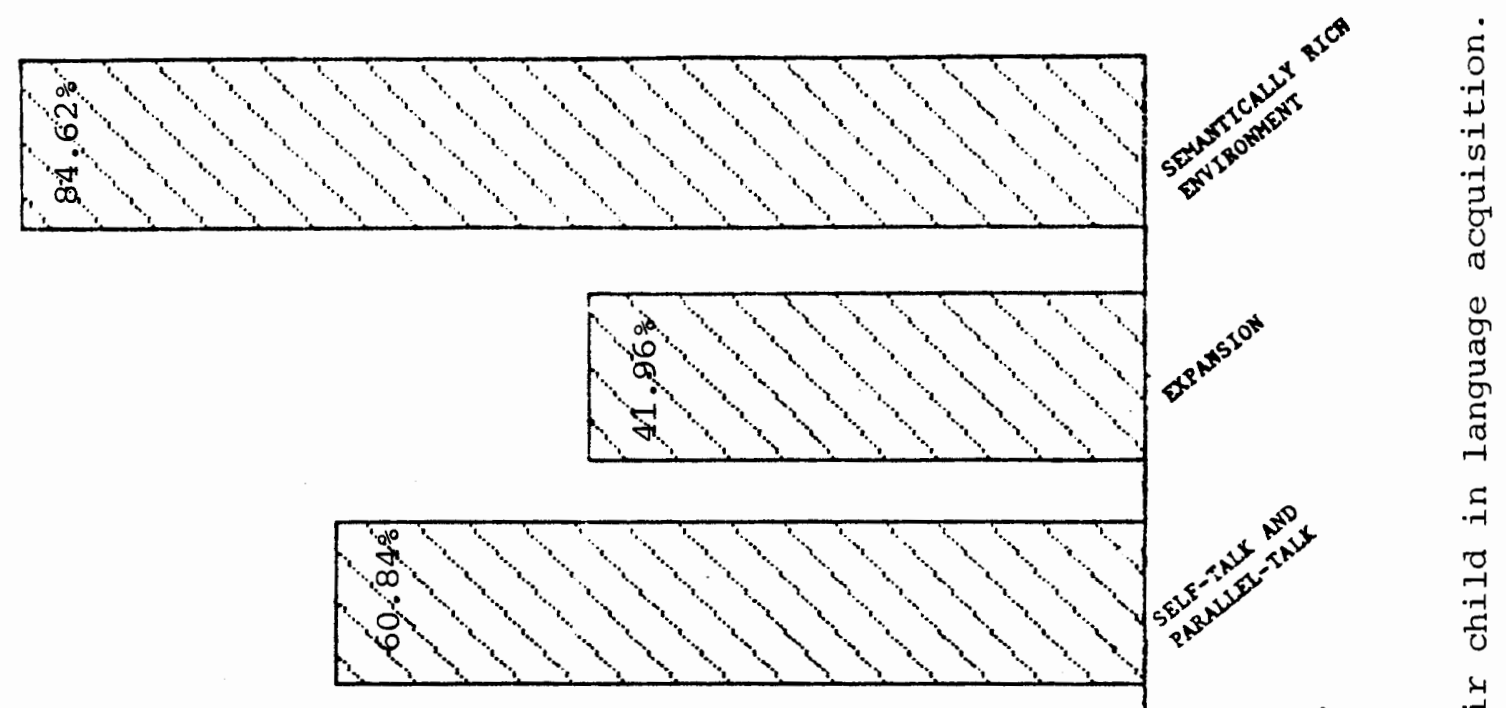

0
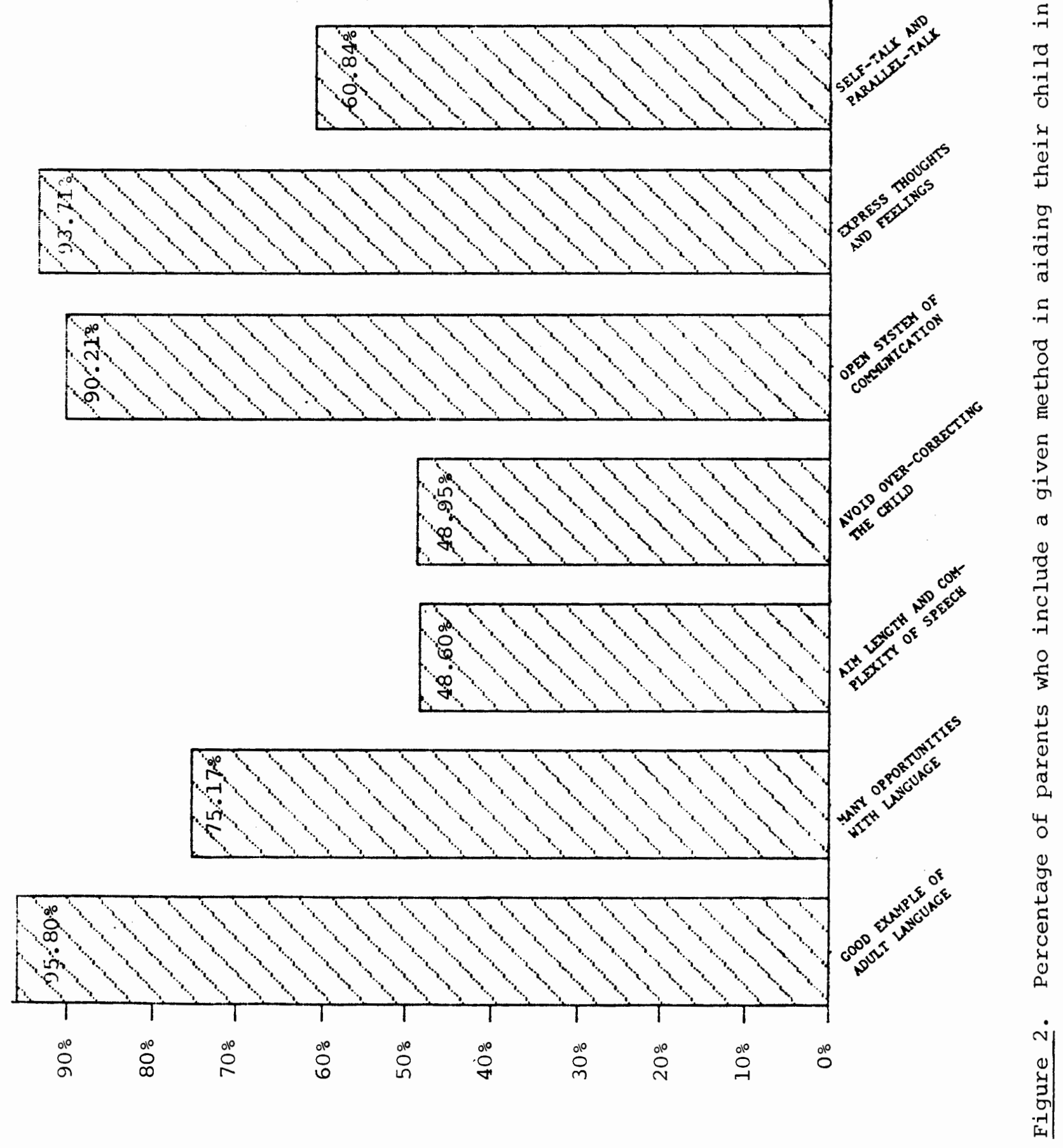

لَ. 


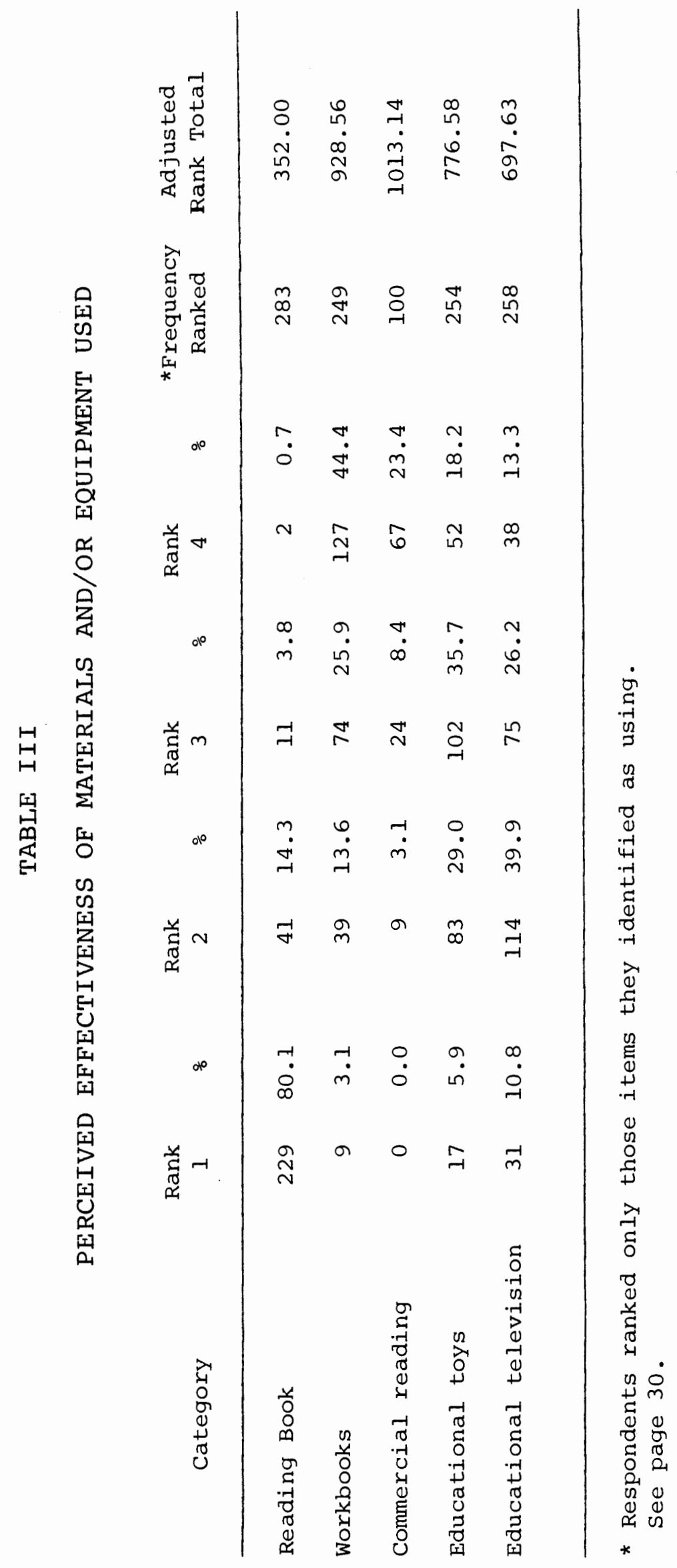


(1) representing the most effective material and/or equipment used and five (5) representing the least effective: reading books (1); educational television programs (2); educational toys (3); workbooks (4); commercial reading programs (5). In Figure 3, these figures are visually demonstrated to aid in analysis. For another perspective on these data, see Table IV where percentage per rank position are relative to percentages within items. This refers to how many respondents ranked an item $1,2,3$, or 4 of those who ranked this particular item.

Language acquisition methods. In Table V, comparison of adjusted rank totals reveal the relative effectiveness of the language acquisition methods used by the parents. The methods were ranked with one (1) representing the most effective language acquisition method used, and five (5) representing the least effective: provide a good example/model of adult language for the child (1); provide an open system of communication (2); provide a semantically rich environment with a lot of opportunities to talk about things and directly experience them ( 3 ); encourage your child to express his/her thoughts and feelings, negative as well as positive (4); aim the length and complexity of your speech to just above the child's level (5); provide many opportunitites for the child to experiment with language, learn communication strategies, and turn-taking (6); encourage talking in your child by using expansion (7); avoid over-correcting your child, but imitate 


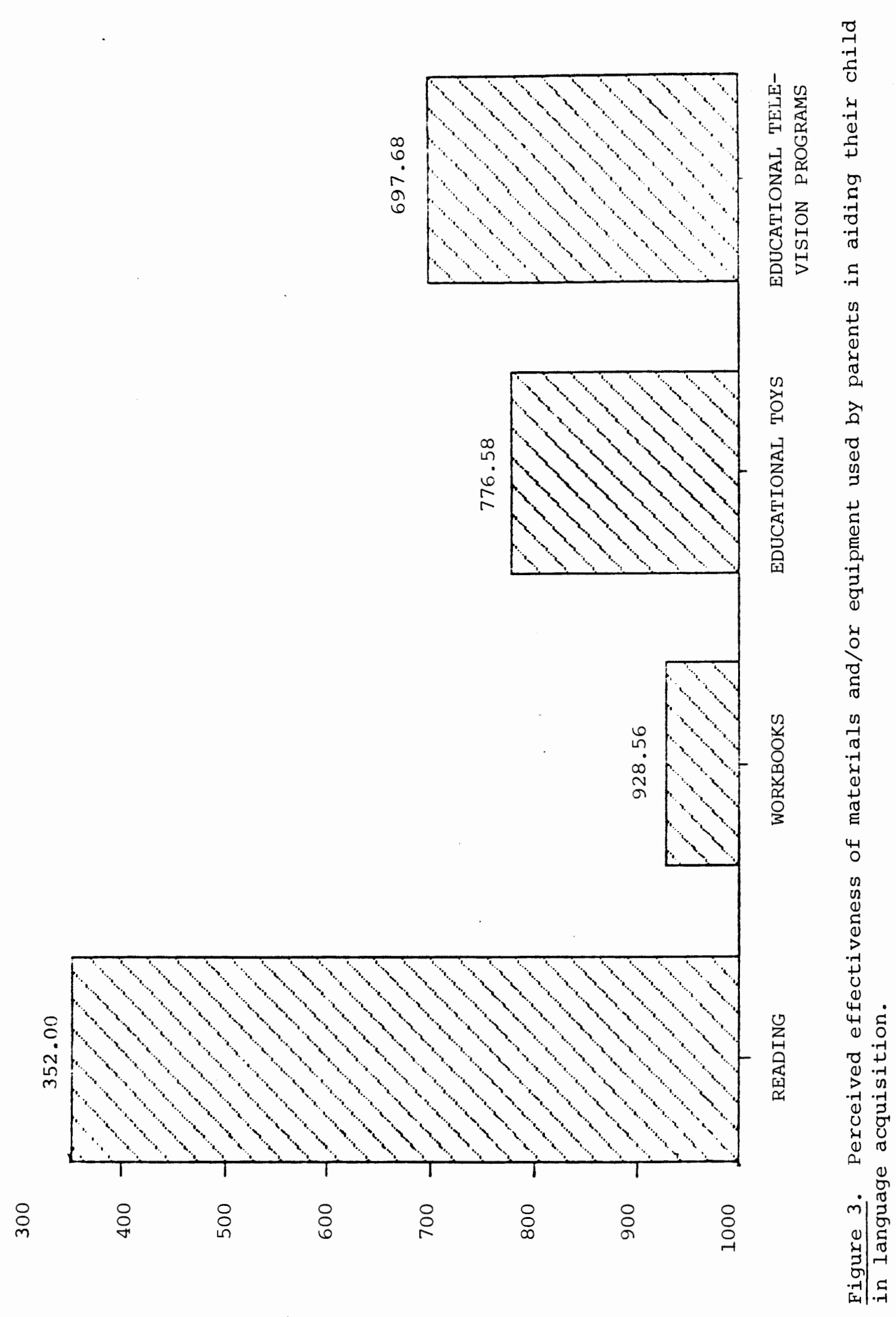




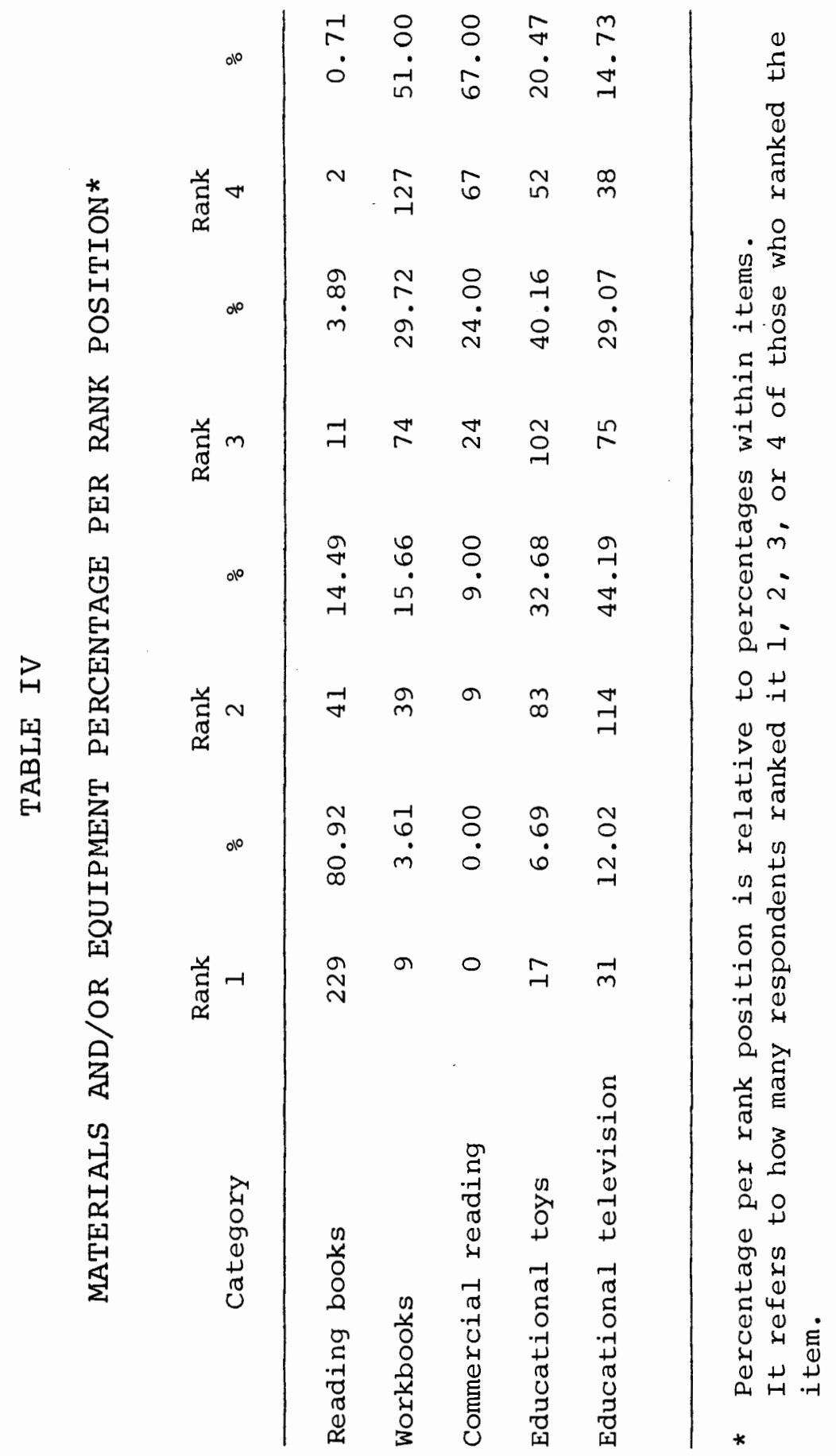




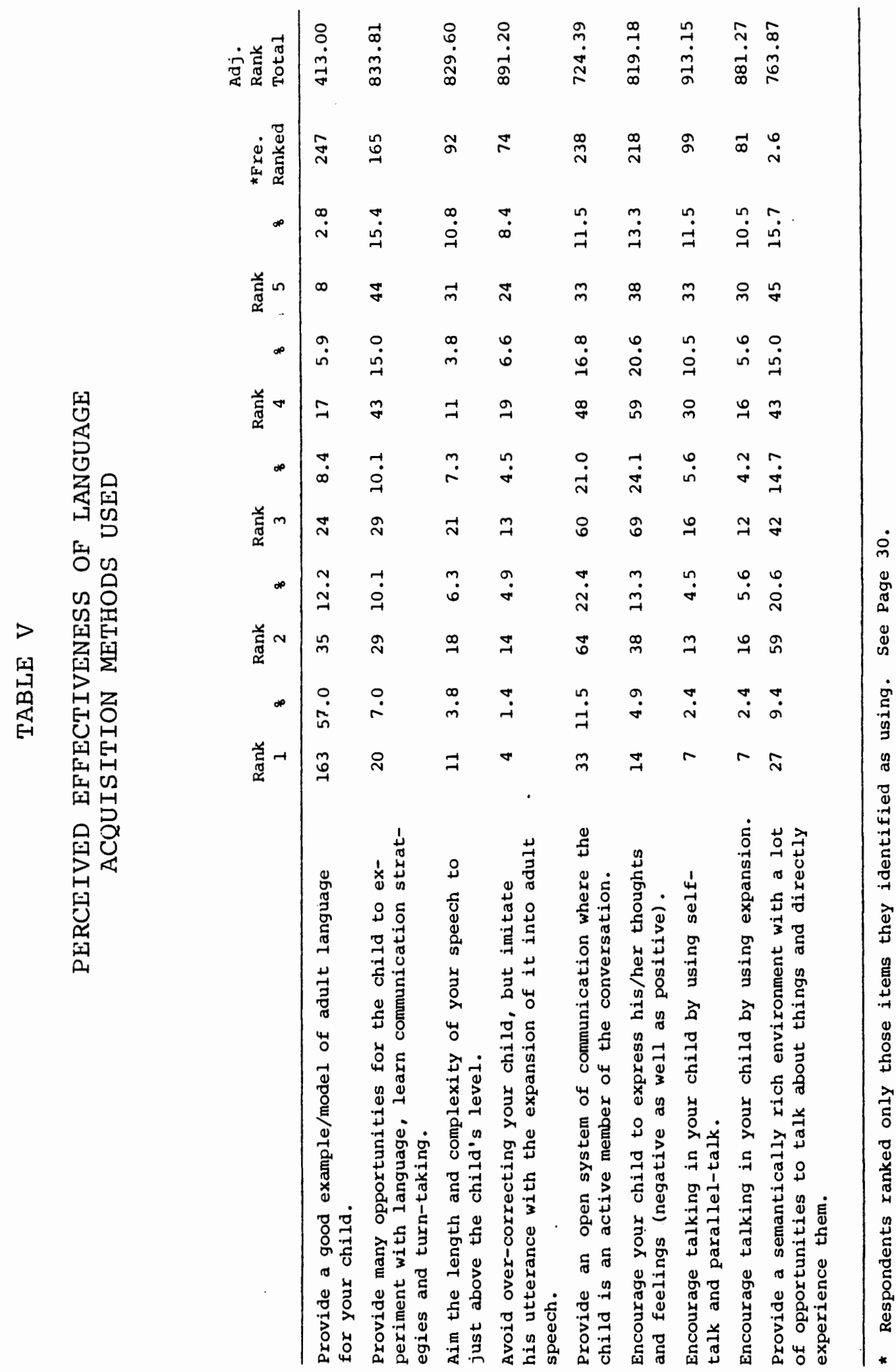


his utterance with the expansion of it into adult speech (8); and encourage talking in your child by using self-talk and parallel-talk (9). Figure 4 visually demonstrates these percentages to aid in analysis. For another perspective on these data, see Table VI where percentages are relative to other percentages within items.

\section{Discussion}

The purpose of this study was to augment existing knowledge of language acquisition in children. Surveys were used to investigate the role parents play in their child's language development and subsequent success in school. Specifically, surveys were used to determine: 1) the materials and/or equipment used and the language acquisition methods employed; and 2) the relative effectiveness of the items employed.

Parental roles in a child's language acquisition can be analyzed in several ways, one being parental attitudes together with the emotional environment they provide. Another way parents play a fundamental role in their child's language acquisition is through the environmental factors provided to stimulate language and the quality of stimulation they provide. Hence, discussion of the data will be discussed under two headings, Materials and/or Equipment, and Language Acquisition Methods, together with percentages used by Respondents and the relative effectiveness of each. 


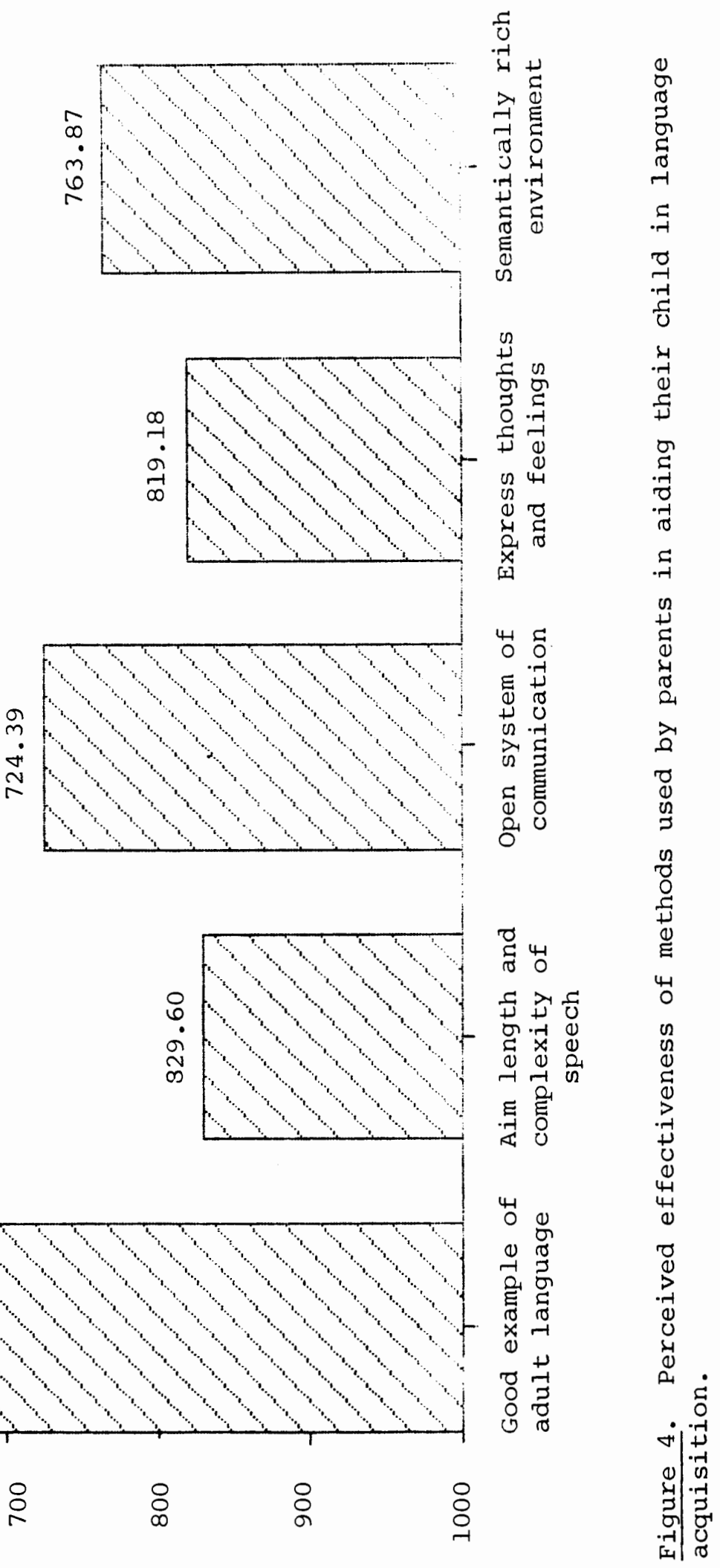




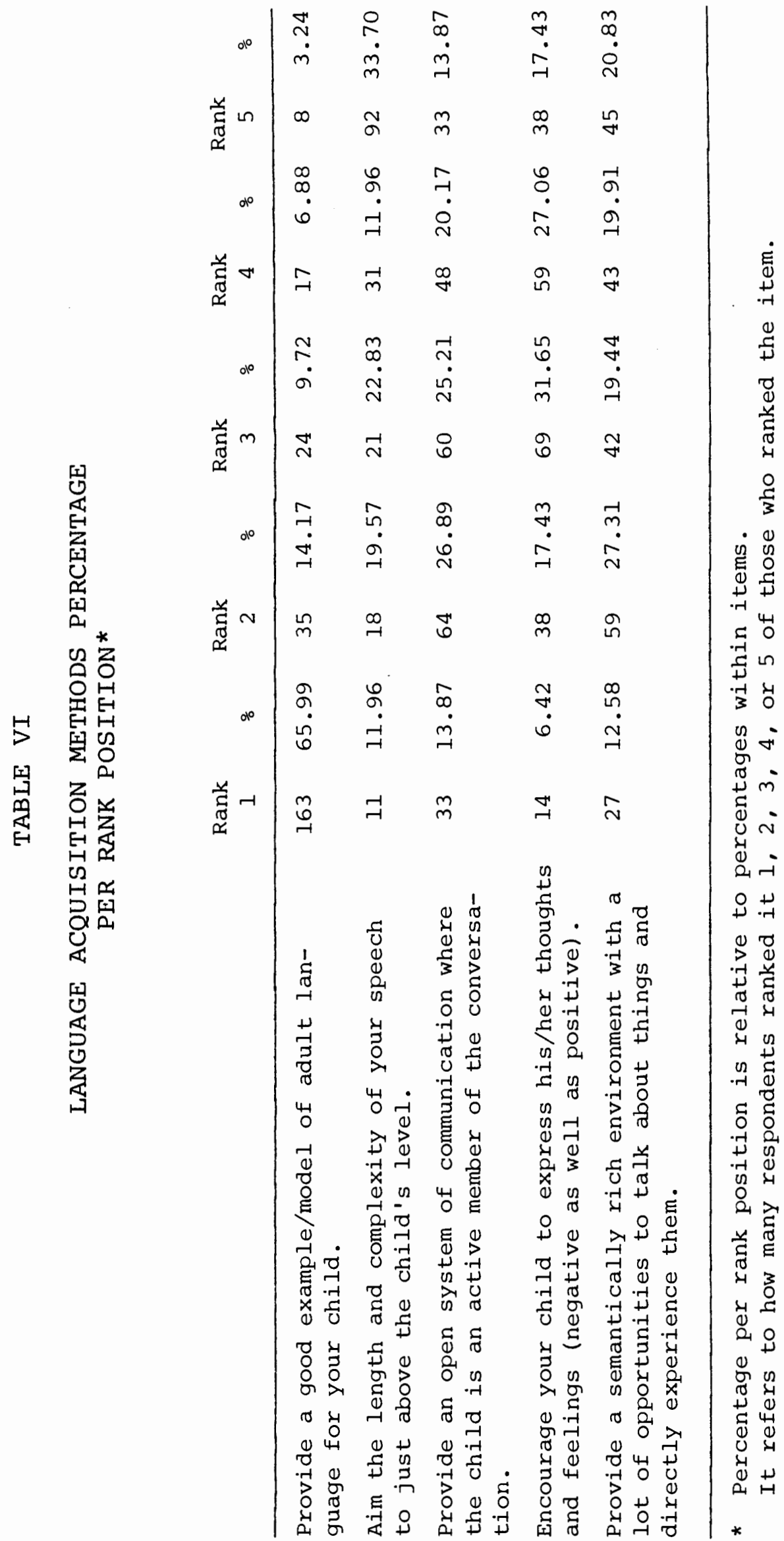


Materials and/or Equipment

Parents were asked what materials and/or equipment they used in aiding their child in language acquisition. Five materials and/or equipment were listed on the questionnaire: 1) reading books; 2) workbooks; 3) commercial reading programs; 4) educational toys; and 5) educational television programs. Spaces were also provided for parents to note additional materials and/or equipment they used.

Reading books. Ninety-seven percent of the respondents reported using reading books with their child (Table I and Figure 1). Reading books were not only the most popular material and/or equipment, but they also were considered to be most effective as is visually demonstrated in Figure 3. The results of these data support literature indicating reading may be one of the most important things a parent can do for a child (Durkin, 1966; Unger, 1976). The high percentage of parents using reading books also supports data indicating the lasting influence reading has on a chila in developing vocabulary, listening skills, and future success in school (Durkin, 1966; Larrick, 1976; Richards, 1978).

Educational television programs. Ninety-three percent of the parents reported educational television programs as the second most widely used material and/or equipment (Table I and Figure 1), as well as ranking it second most effective (Table III and Figure 3). Innovative television programs 
such as Sesame Street, Mr. Rogers, and The Electric Company, originated 15 years ago, aimed at the underprivileged child. It appears from this study that parents from all economic areas benefited from such programs. Television has become the child's theater in the home, and the hours a child spends viewing television are significant (Fliegler, 1961; Larrick, 1976). The results of these data support literature stating many children were aided in acquiring language by watching educational television programs (Fliegler, 1961; Reagan, 1983).

Workbooks. Workbooks were used by 90 percent of the parents (Table I and Figure 1). Workbooks were perceived to be fourth most effective (Table III and Figure 3). One reason for the poor evaluation of workbooks may be that the wording of this item was such that its meaning was unclear. A more meaningful item would have listed several examples of what workbooks included such as paper and pencils, scissors, and manipulative items for the child to see, touch, and hear (Brinley, 1983; Hubbard, 1976; Unger, 1976).

Educational toys. Educational toys were used by 89 percent of the parents, making it the fourth most widely used (Table I and Figure 1). In terms of effectiveness, parents ranked educational toys as the third most effective material and/or equipment (Table III and Figure 3). Games and other toys can serve as motivational material, but they should be used judiciously to ensure they have educational value and 
not merely a busywork measure (Dore et al., 1975; Friedrich, 1983; Larrick, 1976; Ratner and Bruner, 1977; Unger, 1976; Van Hattum, 1982). Data from this study suggest the parents selected games and other toys such as surprise boxes, picture games, and puppetry as indicated by their written-in responses.

Commercial reading programs. While the fifth rank value was excluded from this study due to the large number of parents who listed less than five rank values, 60 percent of the parents reported using commercial reading programs (Table I and Figure 1). If the fifth ranking had been included, it woula have ranked fifth (Table III and Figure 3). There has been a tremendous increase in the availability of commercially developed instructional materials designed and developed for parents to aid their child in language acquisition (Brinley, 1983; Friedrich, 1983; Larrick, 1976). It appears the parents in this study, however, relied more heavily on homemade reading programs and regular reading programs.

Other materials and/or equipment. Other materials and/ or equipment used by parents to promote language acquisition included: a) audio aids ( 6.6 percent); b) visual aids ( 6.9 percent); c) household items ( 1.4 percent); d) machines (.35 percent); and e) schools ( 3.5 percent). Respondents ranked materials and/or equipment reported in the open-ended portion of the questions, other materials and/or equipment used but not listed as a question item. The rank order of only the forced-choice items used by the parents was reported in the 
resulting data (Grove, 1984; Polson, 1980).

Audio aids included such items as records and tapes, radios, and cassettes. Audio aids provided the child with immediate feedback and processing. Efficient processing of auditory language occurs simultaneously at all levels of perceptual, linguistic, and cognitive processing in language competence (Friedrich, 1983; Unger, 1976; Wiig and Semel, $1976)$.

Visual aids included such items as flash cards, sight word pictures, phonic cards, signs (stop and street), photographs, and labels. Many parents listing visual aids noted they were home-made, which again supports literature that parents of the talented and gifted took a personal and active role in their child's development (Casteel, 1982; Dale, 1976; Unger, 1976; Wood, 1976).

Household items included utensils, tools, furniture, and almost any item in the house. These data again reflect the active role these parents took in their child's learning. Many parents added they would point out these items to their child, label them, and talk about them, either alone or with their child as in self-talk and parallel-talk (Van Riper, 1978; Weybright and Rosenthal, 1981).

Machines included items such as typewriters, computers, and microfiche readers. Typewriters have been used effectively in teaching language to children. Children today are living in the computer age where the machine has come to symbolize our informative society. Computers create an ideal 
learning environment, teaching with pictures as well as words and figures (McNitt, 1983). A disadvantage of machines as aids may be the expense, with the price increasing proportionately with the quality of the equipment. Equipment ranges in price from no cost to in excess of several thousand dollars.

Schools included such items as preschool, church school, and play school. These data reflect the parents' active role in stimulating their child which supports literature that parents will seek a tutor or mentor and receive information to guide them in aiding their child's learning process (Bloom and Sosniak, 1981; Brinley, 1983; Callahan and Kauffman, 1992; Friedrich, 1983; Pines, 1982).

\section{Language Acquisition Methods}

Parents were asked which methods they used in aiding their child in language acquisition. Nine language acquisition methods were listed on the questionnaire. Each of these are discussed subtopically below.

Provide a good example/model of adult language for your child. Ninety-five percent of the parents reported using this method (Table II and Figure 2). Providing a good example of adult language not only was the most frequently used method, but it also was considered to be most effective (Table $V$ and Figure 4). An often written comment in this section, as well as other sections of the questionnaire, was that the parents 
never used "baby talk" with their child. Results from this study support the literature that speech models parents present, corrective feedback they offer, and the quality of stimulation they provide are all vital elements in the language acquisition process (Latzke, 1976). Parents are vital in providing role models for their child (Beaverton School District, No. 48. 1982; Pines, 1982). If a large enough corpus of language is made available to the child, he/she will learn more language. Hence, parents should expose the child to a large corpus of language (Casteel, 1982; Dale, 1976; Wood, 1976).

Provide many opportunities for your child to experiment with language, learn communication strategies, and turn-taking. Providing many opportunities for the child to experiment with language, learn communication strategies, and turn-taking was used by 75 percent of the parents, making it the fifth most widely used method (Table II and Figure 2). This method . ranked sixth in terms of effectiveness (Table V and Figure 4). Although this item was not highly ranked, it is compatible with the literature in that these parents encouraged participation in events in which capabilities were displayed publicly (Bloom and Sosniak, 1981; Callahan and Kauffman, 1982; Pines, 1982). Teaching was informal and occurred in a variety of settings for these outstanding individuals in the study by Pines, resulting in the early learning being exploratory and much like play. Expected behaviors, turn-taking, and values 
related to the talent area were present in the family (Pines). Aim the length and complexity of your speech to just above the child's level. Forty-eight percent of the parents reported using this method with their child. It tied as the seventh and eighth most widely-used methods with the item, avoid over-correcting your child, but imitate his utterance with the expansion of it into adult speech (Table II and Figure 2). In terms of effectiveness, it ranked fifth (Table $V$ and Figure 4). It appears from these data that while this method was not widely used, it was felt to be effective by those parents who used it. The strong ranking of this method appears to substantiate the literature that interaction should emphasize semantic considerations of the child's speech (Friedrich, 1983; Wells, 1979; Wood, 1976).

Avoid over-correcting your child, but imitate his utterance with the expansion of it into adult speech. Forty-eight percent of the parents reported using this method with their child. It tied as the seventh and eighth most widely used methods with the item, aim the length and complexity of your speech to just above the child's level (Table II and Figure 2). In terms of effectiveness, this method was ranked as second least effective as is seen in Table $\mathrm{V}$ and visually demonstrated in Figure 4. Many parents wrote comments on the questionnaire that they always corrected their child. The results from these data appear to contradict the literature that imitating the child's utterance with the expansion of it 
into adult speech is important semantic training (Cross, 1979; Van Riper, 1978; Weybright and Rosenthal, 1981).

Provide an open system of conmunication where the child is an active member of the conversation. Ninety percent of the parents reported using this method with their child, making it the third most widely used (Table II and Figure 2). In terms of effectiveness, an open system of communication ranked second (Table $\mathrm{V}$ and Figure 4 ). These results are compatible with the literature stating an open family system provides the child with the best learning environment as pointed out by Wood (1976) in reviewing the work of Bernstein.

Encourage the child to express his/her thoughts and feelings (negative as well as positive). Ninety-three percent of the parents reported using this method, making it the second most widely used as presented in Table II. These data are visually presented in Figure 2 for further analysis. In terms of effectiveness, it was ranked fourth (Table $V$ and Figure 4). The high percentage of parents both using and ranking this method supports the literature indicating children who realize their potential most completely have families that are stimulating, directive, supportive, and rewarding of their special abilities (Callahan and Kauffman, 1982). Early research of the family backgrounds of intellectually gifted children revealed a positive relationship between children's achievement and their parents' encouragement of initiative and independence (Bloom and Sosniak, 1981; Callahan and 
Kauffman, 1982; Pines, 1982; Terman and Oden, 1959).

\section{Encourage talking in your child by using expansion.}

Encouraging talking in the child by using expansion has been a technique described frequently in the literature (Cazden, 1972; Casteel, 1982; Dale, 1976; Weybright and Rosenthal, 1981; Wood, 1976). In contrast to the abundance of literature purporting this to be an effective technique, only 41 percent of the parents in this study used expansion, making it the least frequently used item. This is presented in Table II and visually demonstrated in Figure 2. In terms of effectiveness, this item was ranked seventh (Table $V$ and Figure 4). The data from this study appear to contradict the literature that expansion is one of the vital elements in the language acquisition process.

Encourage talking in your child by using self-talk and parallel-talk. Self-talk and parallel-talk techniques discussed by Weybright and Rosenthal (1981) are other methods of assisting a child in language acquisition. Sixty percent of the parents reported including self-talk and parallel-talk with their child, making it the sixth most widely used method (Table II and Figure 2). In terms of effectiveness, it was ranked as least effective (Table $V$ and Figure 4). Hence, while these data appear to contradict the literature supporting self-talk and parallel-talk, it is perceived by this investigator that a significant number of these parents indeed did use these methods as evidenced by their written comments 
next to other items, such as educational toys, educational television, and reading books. It is further posed that many of these parents did not know about such methods.

Provide a semantically rich environment with a lot of opportunities to talk about things and directly experience them. Providing a semantically rich environment with a lot of opportunities to talk about things and directly experience them was the fourth most widely used method (Table II and Figure 2), as well as ranking third in terms of effectiveness (Table $V$ and Figure 4). Eighty-four percent of the parents reported using this method with their children. These results further support the literature that children will not "bloom on their own" and need parental support and stimulation (Bloom and Sosniak, 1981; Callahan and Kauffman, 1982; Pines, 1982). Pines found in his study of successful individuals that one of the important factors in determining a child's high potential was that there was specific parental encouragement of the child to explore the area, participate in home activities related to it, and join the family in related activities. These small signs of interest and capability by the child were rewarded. Parents took for granted their child would learn in the talent area, just as the child would learn language.

The results presented and discussed above clearly indicate the answers to the two questions posed in this study have been answered. 
Demographic Data

Although demographic data were not a part of the present study in terms of its probable purpose and the questions to be answered, this investigator felt there was certain essential information needed to describe the respondents to the questionnaire and certain things relative to the children of the respndents. Hence, a section called Demographic Data was developed.

The first portion of the survey, asking which grade the parents had TAG student(s) was designed to yield the percentage of parents responding to this question from each of the three grades, fourth, fifth, and sixth, and to determine equal representation. Seventy-three out of 92 fourth grade parents answered this question (79 percent). One-hundrednine out of 144 fifth grade parents answered this question (74 percent). One-hundred-four out of 172 sixth grade parents answered this question (60 percent). Overall response rate is one guide to the representativeness of the sample of respondents. When a high response rate is achieved, there is less chance of significant bias. A response rate of at least 60 percent is good, and a response rate of 70 percent or more is very good (Babbie, 1973). In this present study, a response rate of 70 percent was achieved.

Ninety-four percent of all parents answered the question of when their child said his/her first word with the responses ranging from 3 months to 30 months with a mean of 
9.99 months, slightly younger than the upper age limits at which children should be using words (English, 1981; Gordon, 1981). Ninety-three percent of the parents from all grades answered the question of when their child said his/her first sentence, with responses ranging from 5 months to 48 months with a mean of 19.36 months, 5 months younger than the upper age limits at which most children began speaking in sentences (English and Gordon). Ninety-nine percent of the parents answered the question of when their child began reading with the responses ranging from 18 months to 84 months with a mean of 55.22 months, $21 / 2$ years younger than the upper age limits at which most children began reading (English and Gordon). The results of these data suggest these TAG children were advanced for their developmental age in acquiring language.

One hundred percent of the respondents reported their level of education. The mothers' level of education ranged from 11.9 percent reporting high school as their highest grade attained to 2.8 percent listing a doctorate degree (or equivalent) as the highest level. The mean for the mothers' level of education was 15.27 years of schooling, and the mode was 40.2 percent having a bachelor's degree. The fathers' level of education was 3.5 percent reporting a high school education as the highest level of education attained to 16.8 percent listing a doctorate (or equivalent) as the highest level of education. The mean for the fathers' level of education was 16.27 years of schooling. The mode for the fathers' level of education was 34.3 percent having a bachelor's degree. 
The literature revealed it is frequently assumed parents of talented and gifted children are gifted, will know the most appropriate strategies, and have the necessary resources for dealing with giftedness at home and at school. The literature further suggested both this assumption and conclusion were often false (Passow, 1979; Robinson, 1977). The results of this study appear to contradict the literature in that the parents in the present study had a high level of education. While education is not the only determiner for intelligence or skills in parenting, it is a barometer most frequently employed in research studies (Babbie, 1973).

One hundred percent of the parents responded to the question of which parent completed the questionnaire. Ninety percent of all respondents were mothers, with 8.7 percent being the father, and 1 percent of the respondents indicating "both parents" completed the questionnaire. These data are compatible with the literature that the mother spends the most time with the child (Brinley, 1983; Cross, 1979; Friedrich, 1983; Snow, 1972, 1979; Unger, 1976). In Appendix D, these figures are visually demonstrated to aid in analysis. 


\author{
CHAPTER V \\ SUMMARY AND IMPLICATIONS
}

Summary

The ability to communicate is perhaps the most important gift afforded mankind, and any breakdown in this process greatly affects one's well being. Education begins in the cradle as auults are constantly talking and exposing the child to speech and to experiences that give him or her language (Hearsay, 1978).

Children's performance in school settings as well as their behavior in social groups is based upon their ability to communicate meanings to others. Children who are able to use words to express fine distinctions in meaning will more successfully communicate their feelings, ideas, and attitudes to others (Wood, 1976). Parents are considered to be the major source of stimulation within the child's environment throughout the developmental years (Latzke, 1975).

Most of the studies on language acquisition techniques provided by parents have been addressed to the training of parents for prevention of language disabilities and disorders (Latzke, 1975). Few investigations have involved language acquisition of the superior functioning child (Patterson, 1981). Hence, the purpose of this study was to survey 
language acquisition techniques provided by parents of talented and gifted children (TAG) who were enrolled in the Beaverton School District, Number 48 TAG program. The first question dealt with what materials and/or equipment did the parents use in aiding their child's language development. The second question dealt with which particular methods did the parents use in aiding their child in language acquisition. The results of language acquisition methods and materials and/or equipment used in aiding language acquisition for their children was derived from answers to a questionnaire sent to 408 parents of TAG children in Beaverton, Oregon. Two hundered and eighty-six (70 percent) of the 408 questionnaires returned were used in the tabulation of results.

Parents of the TAG students participating in this study employed a variety of materials and/or equipment in aiding their child's language acquisition. Reading books and educational television were the two most frequently used materials and/or equipment used by the parents. Reading books and educational television also were perceived as being most effective by the parents.

Parents of the TAG students participating in this study employed a variety of language acquisition methods. Four language acquisition methods were reported used by 85 percent or more of the respondents to this survey: provide a good example/model of adult language; encourage the child to express his/her thoughts and feelings (negative as well as positive); provide an open system of communication where the child is an 
active member of the conversation; and provide a semantically rich environment with a lot of opportunities to talk about things and directly experience them. These four methods were also perceived as being most effective by the parents. In summary, the results showed that the parents of the TAG children were very active participants in their children's language acquisition, and the children were very active members of the conversation, free to express their thoughts and feelings. The findings of this investigation are also related to the results of the Bloom and Sosniak (1981) study of exceptionally talented and gifted children and the effect their parents had on their future.

\section{Clinical Implications}

The Bloom and Sosniak (1981) study identified several conditions standing apart from native giftedness of children which appear to be crucial in producing excellence. Results from the parents of the TAG children in this present study closely parallel and strongly support these same crucial elements. It is known that gifted children will not ordinarily "blossom" to the full extent on their own (Guilford, 1975). The challenge of the gifted and talented provides parents and educators with opportunities to re-examine the conceptual framework of education.

The results of this study present evidence for training parents in methods of language stimulation for the young child. It was found that three out of four language 
acquisition methods dealt with positive parental interaction. This parental interaction with the child appeared to be a strong factor, which might be of value for clinical application with children who are having speech and language problems. Hence, parent training programs such as those of Weybright and Rosenthal (1981) might be used to teách parents effective methods in speaking to and with their children. The results of this study, particularly the percentage tables, can be used by the Speech-Language Pathologist to educate parents as to the importance of an open system of communication where the child is an active member of the conversation, free to express his/her thoughts and feelings. The present investigation tended to suggest strong evidence for using reading books, educational television, and educational toys to their maximum potential in aiding language. The clinician can use this information to plan materials for the clinic and to plan carryover activities for the parents to use with their children.

\section{Research Implications}

Questionnaires of the nature in this study often generate additional questions to be explored. Replication of the study with a different socioeconomic population might yield interesting data for comparison. Similar research with other districts would add to current knowledge about language acquisition.

Another area of the questionnaire which would warrant 
in-depth analysis would be that of parental encouragement and degree of reinforcement. Contrary to literature advising against continuous reinforcement due to its rapid rate of extinction, many parents of the TAG children in this study reported rewarding even the slightest accomplishment of their child which substantiates the results of the Bloom and Sosniak (1981) study.

A third area of possible study would be a more in-depth analysis of materials and/or equipment. Several areas not written on the questionnaire but frequently written in by parents were audio aids, visual aids, and musical intsruments. This investigator did not foresee the importance of materials and/or equipment; hence, it is suggested that the importance of this area be investigated.

A fourth thrust of research may be parent training programs designed specifically for enrichment in their children. Investigation of this area would provide information on the innate abilities of the parents versus those parents who specifically sought out parent training.

Parental intelligence may be a fifth area worthy of future study. It is suggested for future studies that a more in-depth analysis be made to determine which, if any, parents were members of Mensa; which, if any, parents were themselves considered gifted children.

The old saw that "genius will out" in spite of circumstances was not substantiated in the study by Bloom and Sosniak (1981) nor in this present study. Future research may 
be directed toward the key factors in the Bloom and Sosniak study which were felt to be vital for a child's development of full potential; e.g., What does the home value? How much encouragement does the child receive at an early age?

Although no attempt was made to validate the instrument, this investigator would suggest that it might be useful to develop and validate a questionnaire similar to the one used in this investigation. Particular attention would need to be given to defining and illustrating the subitems of the several categories in order to communicate to the respondents the exact information being requested.

It is hoped that with this increased knowledge, relative to exceptionally able children, speech-Language Pathologists can better intervene to aid parents in improving the communicative competence of the children with whom they work. 


\section{SELECTED BIBLIOGRAPHY}

ALVINO, J., MCDONNEL, R.C., RICHERT, S. (1981). National survey of identification practices in gifted and talented education. Exceptional Children, 48, 124-133.

BABBIE, E.I. (1973). Survey research methods. Belmont, CA: Wadsworth Publishing Company.

BEAVERTON SCHOOL DISTRICT, NO. 48. (1982). TAG Handbook.

BLOOM, B.S., and SOSNIAK, L.A. (1981). Talent development vs. schooling. Educational Leadership, 39, 86-94.

BLOOM, L., and LAHEY, M. (1982). Language development and language disorders. New York, NY: John Wiley and Sons.

BRINLEY, M.B. (1983). Raising a superkid. McCalls, November, 101-102.

BURGESS, B. (1976). Facts and figures: A layman's guide to conducting surveys. Institute for Responsive Education.

CALLAHAN, C.M. and KAUFFMAN, J.M. (1982). Involving gifted children's parents: Federal law is silent, but its assumptions apply. Exceptional Education Quarterly, $3,2,50-55$.

CASTEEL, R. (1982). Lecture in Speech 580, Portland state University.

CAZDEN, C. (1972). Child language and education. New York, NY: Holt, Rinehart and winston, 146-152.

CROSS, T.G. (1979). Mothers' speech adjustments and child language learning: Some methodological considerations. Language Sciences, 1, $\mathrm{nl}, 3-25$.

DALE, O.S. (1976). Language development: Structure and function. New York, NY: Holt, Rinehart and Winston, 146-152.

DARLEY, F.I., and SPRIESTERBACH, D.C. (1978). Diagnostic methods in speech pathology (2nd ed.). New York, NY: Harper and Row Publishers.

DILLMAN, D.A. (1978). Mail and telephone surveys: The total design method. New York, NY: John Wiley and Sons. 
DORE, J., FRANKLIN, M.B., MILLER, R.T., RAMER, A.L.H. (1975). Transitional phenomena in early language acquisition. Child Language, 13-28.

DURKIN, D. (1966). Children who read early. New York, NY: Teacher's College Press.

ENGLISH, R.H. (1981). Lecture in Speech 481, Portland state University.

FLIEGLER, L.A. (1961). Curriculum planning for the gifted. Englewood Cliffs, NJ: Prentice-Hall, Inc.

FRIEDRICH, O. (1983). What do babies know? Time, August 15, 52-59.

GORDON, M. (1981). Lecture in Speech 481, Portland state University.

GROVE, T.G. (1984). Lecture in Speech 510A, Portland state University.

GUILFORD, J.P. (1975). Varieties of creative giftedness, their measurement and development. Gifted Child Quarterly, 19, 107-121.

HEARSAY, (1978). Portland Center for Hearing and Speech, 17, (5).

HOPPER, R., and NAREMORE, R. (1973). Children's speech: A practical introduction to communication development. New York, NY: Harper \& Row.

HUBBARD, D. (1976). Learning to talk. Times Educational Supplement (London), 3180, 18-19.

KERLINGER, F.N. (1964). Foundations of behavioral research (2nd ed.). New York, NY: Holt, Rinehart and Winston, Inc.

LARRICK, N. (1976). From 'hands off' to 'parents, we need you!' Childhood Education, 52, (3).

LATZKE, D.D. (1975). "Implications for parent involvement within a language development program." Master's thesis, Portland State University, Portland, Oregon.

LATZKE, D.D. (1976). "Parent involvement within a language development program: Pilot study." Master's thesis, Portland State University, Portland, Oregon.

MATHEWS, F.N. (1981). Influencing parents' attitudes toward gifted education. Exceptional Children, 48, (2), 134 . 
MCNITT, J. (1983). Do home computers help kids learn? People, November 28 .

MOERK, E.L. (1976). Processes of language teaching and training in the interactions of mother-child dyads. Child Development, 47, 1064-1078.

MOSER, C.A., and KALTON, G. (1971). Survey methods in social investigation ( 2 nd ed.). London: Heinemann Educational Books Ltd.

NELSON, K.E., CARSKADDON, G., and BONVILIIAN, J.D. (1976). Syntax acquisition: Impact of experimental variation in adult verbal interaction with the child. Child Development, 44,497-504.

PASSOW, A.H. (Ed.) (1979). The gifted and talented. Chicago, IL: University of Chicago Press.

PATTERSON, J. (1981). A message from the president of TAG. Exceptional Children, 48, (2), 105.

PHILIIPS, J. (1973). Syntax and vocabulary of mothers in young children: Age and sex comparisons. Child Development, $44,132-185$.

PINES, M. (1982). Parental involvement found key in realizing child's potential. The Oregonian, April 19.

POLSON, J.M. (1980). "A survey of carryover practices of public school clinicians in Oregon." Master's thesis, Portland State University, Portland, Oregon.

RATNER, N., and BRUNER, J. (1977). Games, social exchange and the acquisition of language. Child Language, 3 , 391-401.

REAGAN, R. (1983). To know a genius. Parade Magazine, October 2 .

RICHARDS, S. (1978). Reading to children is important to them. Oregon Journal, November 13.

ROBINSON, H.B. (1977) . Current myths concerning gifted children. In Gifts, talents and the very young. Ventura, CA: National/State Leadership Training Institute on the Gifted and Talented.

SEITZ, S., and STEWART, C. (1975). Imitations and expansions: Some developmental aspects of mother-child communication. Developmental Psychology, 11, 763-768. 
SNOW, C.E. (1972). Mothers' speech to children learning language. Child Development, 43, 549-565.

SNOW, C.E. (1979). Mother's speech research: From input to interaction. Talking to children: Language input and acquisition. New York, NY: Cambridge University Press.

SUDMAN, S., and BRADBURN, N. (1982). Asking questions: A practical guide to questionnaire design. San Francisco, CA: Jossey-Bass Publishers.

TERMAN, L., and ODEN, M. (1959). Genetic studies of genius. The gifted group at midlife. Stanford, CA: Stanford University Press.

THOMASON, J. (1981). Education of the gifted: A challenge and a promise. Exceptional Children, 48, (2), 101-104.

UNGER, D.M. (1976). It's never too early: Developing language skills in the very young child. Teaching Exceptional Children, 8, (3), 126-127.

VAN HATTUM, R.J. (1982). Speech-language programming in the schools. Springfield, IL: Charles C. Thomas Publishing Company.

VAN RIPER, C. (1978). Speech correction: Principles and methods ( 6 th ed.). Englewood Cliffs, NJ: PrenticeHall, Inc., 137-138.

WELLS, G. (1979). Variations in child language. Language Acquisition. New York, NY: Cambridge University Press, 377-395.

WEYBRIGHT, G., and ROSENTHAL, J. (1981). Helping children learn to talk. Child Care Resources.

WIIG, E.I., and SEMEL, E.M. (1976). Language disabilities in children and adolescents. Columbus, $\mathrm{OH}$ : Charles E. Merril Publishing Company.

WOOD, B.S. (1976). Children and communication: Verbal and nonverbal language development. Englewood Cliffs, NJ: Prentice-Hall, 50-57.

WOODLEY, R. (1983). Want to raise a genius? People, August $29,32-34$. 


\section{APPENDIX A}

\section{QUESTIONNAIRE}

NOTE: Please do not sign your name on this questionnaire.

\section{LANGUAGE ACQUISITION QUESTIONNAIRE}

In which grade/s do you have TAG student/s?

$\begin{array}{r}4 \\ -\quad 5 \\ \hline-6\end{array}$

MOTHER'S LEVEL OF EDUCATION

1. High School

2. College (No. of years)

3. Bachelors

4. Masters

5. Doctorate

6. Other (Specify)
At which age did your child? (Estimate)

Say first word Speak in sentences Begin reading

\section{FATHER'S LEVEL OF EDUCATION}

1. High School

2. College (No. of years)

3. Bachelors

4. Masters

5. Doctorate

6. Other (Specify)

LANGUAGE ACQUISITION TECHNIQUES for the purpose of this study refers to particular methods you used in teaching your child to speak, read and acquire knowledge.

All of the following questions deal with language acquisition. Please respond in terms of what you did to promote language learning in your child. If this is a two parent family, would the parent with the most contact with the child fill out this section? Please identify which parent completed the questionnaire by circling:
A. Mother
B. Father

I. What materials and/or equipment did you use to promote language acquisition? Circle the number/s corresponding to ANY MATERIALS AND/OR EQUIPMENT you used. Rank order from those you circled the five you found most effective, one (1) being the most effective.

CIRCLE those you used

1. P.eading books

2. Workbooks

3. Commercial reading programs

4. Educational toys

5. Educational television programs

6. Other (Specify)

7. Dther (Specify)

8. Other (Specify)
RANK ORDER only those you circled 1 = most effective 
II. Which of the following methods did you use in aiding your child in language acquisition? Circle any number/s corresponding to ANY METHOD/S you used. Rank order from those you circled the five you found most effective, one (1) being the most effective.

CIRCLE those

RANK ORDER ON 1 Y you used those you circled 1 = most effective

1. Provide a good example/model of adult language for your child.

2. Provide many opportunities for the child to experiment with language, learn communication strategies and turn taking.

3. Aim the length and complexity of your speech to just above the child's level.

4. Avoid over-correcting your child, but imitate his utterance with the expansion of it into adult speech.

5. Provide an open system of communication where the child is an active nember of the conversation.

6. Encourage your child to express his/her thoughts and feelings (negative as well as positive).

7. Encourage talking in your child by using self-talk (talk aloud about what your child is doing).

8. Encourage talking in your child by using parallel talk (talk about what your child is doing).

9. Encourage talking in your child by using expansion (Exactly imitate what your child is saying and then add to it in a more acceptable gramnatical form).

10. Provide a semantically rich environment with a lot of opportunities to talk about things and directly experience them. 


\section{APPENDIX B}

\section{COVER LETTER}

Dear Parent:

I am the parent of a TAG student doing a master's thesis on language acquisition techniques provided by parents of talented and gifted children.

As a parent of a TAG student at the C. E. Mason School, you were selected for participation in this study. Please share your opinions and ideas concerning language acquisition by filling out the enclosed questionnaire. The results of this research will be the basis of my master's thesis.

To allow ample time to compile results and analyze data, I would appreciate receiving your results by February 20, 1984.

You may be assured of complete confidentiality. I would be happy to answer any questions you might have. Please write me at 6250 SW Erickson, Beaverton, OR 97005, or call me at 646-1805.

Thank you for your assistance!

Sharon Engen

I have read and understand the foregoing information.

Date Signature

If you experience problems that are the result of your participation in this study, please contact Director of Sponsored Research, Office of Graduate Studies and Research, 105 Neuberger Hall, Portland State University, 229-342j. 


\section{APPENDIX C}

\section{FOLLOW-UP POSTCARD}

Dear Parent:

Two weeks ago, a questionnaire seeking your opinion on language acquisition techniques was mailed to you.

If you nave already completed and retumed the questionnaire, please accept my sincere thanks. If not, please do so today. Because this questionnaire was sent to only parents of TAG children, it is extremely imeortant that you be included in the study if the results are to be accurately representative.

If by soxe chance you did not receive the questionnaire, or it got misplaced, please call the at 646-1805, and $I$ will put another one in the mail to you today.

Thank you.

Sharon Engen 
APPENDIX D

DEMOGRAPHIC DATA

\begin{tabular}{|c|c|c|c|}
\hline \multicolumn{4}{|c|}{ PERCENTAGE RESPONDING } \\
\hline Grade & $\begin{array}{l}\text { Total } \\
\text { Enrolied }\end{array}$ & $\begin{array}{l}\text { Total } \\
\text { Responding }\end{array}$ & \\
\hline $\begin{array}{l}4 \\
5 \\
6\end{array}$ & $\begin{array}{r}92 \\
144 \\
172\end{array}$ & $\begin{array}{r}73 \\
109 \\
104\end{array}$ & \\
\hline TOTAL & 408 & 286 & 70 \\
\hline
\end{tabular}

\begin{tabular}{lcr}
\cline { 1 - 2 } WHICH PARENT & RESPONDED & \\
\cline { 1 - 2 } Parent & Total & \\
ResDonding & $\frac{6}{258}$ & 90.2 \\
Mother & 25 & 8.7 \\
Father & 3 & 1.0 \\
Both & 286 & 99.9 \\
TOTAL & &
\end{tabular}

\section{EDUCATION LEVEL OF PARENTS}

\begin{tabular}{|c|c|c|c|c|c|c|c|}
\hline Parent & Level & $\begin{array}{l}\text { Total } \\
\text { Resoonding }\end{array}$ & $\underline{q}$ & Parent & Level & $\begin{array}{l}\text { Total } \\
\text { Respondin }\end{array}$ & \\
\hline $\begin{array}{l}\text { Mother } \\
\text { Mother } \\
\text { Mother } \\
\text { Mother } \\
\text { Mother } \\
\text { Mother } \\
\text { Mother } \\
\text { Mother } \\
\text { Mother }\end{array}$ & $\begin{array}{l}\text { High School } \\
\text { Collece-1 yr. } \\
\text { College-2 yrs. } \\
\text { College-3 yrs. } \\
\text { College-4 yrs. } \\
\text { Bachelors } \\
\text { Masters } \\
\text { Doctorate } \\
\text { Others }\end{array}$ & $\begin{array}{r}34 \\
26 \\
38 \\
11 \\
19 \\
115 \\
29 \\
8 \\
6\end{array}$ & $\begin{array}{r}11.9 \\
9.1 \\
13.3 \\
3.8 \\
6.6 \\
40.2 \\
10.1 \\
2.8 \\
2.1\end{array}$ & $\begin{array}{l}\text { Father } \\
\text { Father } \\
\text { Father } \\
\text { Father } \\
\text { Father } \\
\text { Father } \\
\text { Father } \\
\text { Father } \\
\text { Father }\end{array}$ & $\begin{array}{l}\text { High School } \\
\text { College-1 yr. } \\
\text { College-2 yrs. } \\
\text { College-3 yrs. } \\
\text { College-4 yrs. } \\
\text { Bachelors } \\
\text { Masters } \\
\text { Doctorate } \\
\text { Others }\end{array}$ & $\begin{array}{r}10 \\
11 \\
23 \\
13 \\
21 \\
98 \\
61 \\
48 \\
1\end{array}$ & $\begin{array}{l}3.5 \\
3.8 \\
8.0 \\
4.5 \\
7.3 \\
34.3 \\
21.3 \\
16.8 \\
0.8\end{array}$ \\
\hline
\end{tabular}

AGE AT WHICH CHILD SAID FIRST WORD, FIRST SENTENCE, BEGAN READING

First Word

Months Responses

$\begin{array}{rr}0 & 16 \\ 3 & 1 \\ 4 & 5 \\ 5 & 6 \\ 6 & 30 \\ 7 & 15 \\ 8 & 25 \\ 9 & 42 \\ 10 & 27 \\ 11 & 11 \\ 12 & 68 \\ 13 & 5 \\ 14 & 3 \\ 15 & 5 \\ 16 & 2 \\ 18 & 13 \\ 20 & 1 \\ 21 & 1 \\ 22 & 1 \\ 24 & 7 \\ 26 & 1 \\ 30 & 1\end{array}$

First Sentence

Months Responses

$\begin{array}{rr}0 & 20 \\ 5 & 1 \\ 6 & 1 \\ 9 & 1 \\ 10 & 8 \\ 11 & 3 \\ 12 & 27 \\ 13 & 11 \\ 14 & 8 \\ 15 & 14 \\ 16 & 13 \\ 17 & 1 \\ 18 & 45 \\ 19 & 3 \\ 20 & 4 \\ 21 & 2 \\ 23 & 1 \\ 24 & 80 \\ 27 & 3 \\ 28 & 1 \\ 30 & 15 \\ 33 & 2 \\ 36 & 17 \\ 42 & 3 \\ 48 & 2\end{array}$

Started to Read

Months Responses

$\begin{array}{rr}0 & 2 \\ 18 & 2 \\ 24 & 2 \\ 30 & 1 \\ 36 & 25 \\ 42 & 7 \\ 45 & 1 \\ 48 & 73 \\ 49 & 1 \\ 54 & 12 \\ 57 & 1 \\ 60 & 101 \\ 66 & 16 \\ 68 & 2 \\ 72 & 34 \\ 74 & 1 \\ 78 & 2 \\ 84 & 3\end{array}$

